\title{
Artículos
}

\section{Predicación y profecía. Análisis de las homilías de Monseñor Romero}

\author{
Miguel Cavada Diez
}

\section{Resumen}

Monseñor Romero ejerció su labor pastoral de diversas formas, pero fue conocido sobre todo a través de las homilías dominicales, que causaron gran conmoción en la sociedad. La comunicación que se establecía entre Monseñor Romero y su pueblo, y la influencia de las homilías en la vida de las personas e instituciones del país no tiene precedente alguno en la Iglesia y en la sociedad salvadoreñas. Hay que preguntarse, por lo tanto, ¿qué tenía aquella palabra que los pobres recibian como auténtica "buena noticia" y que ciertos grupos influyentes no soportaron hasta el punto de ordenar su asesinato? ¿Qué tienen las homilias de Monseñor Romero que tanto impacto causaron?

\section{Introducción}

Monseñor Romerol ejerció su labor pasioral de diversas formas, pero fue conocido sobre todo a través de las homilías dominicales ${ }^{2}$ en la catedral de la arquidiócesis de San Salvador. Su palabra y su obra causaron gran conmoción en la sociedad salvadoreña. Estas homilías, transmitidas por la emisora católica YSAX, eran esperadas con gran expectación, tanto por el pueblo sencillo que lo escuchaba con atención y agradecimiento como por sus detractores que buscaban la ocasión para calumniarlo. Y ya antes de su muerte, pero sobre todo después de su martirio, sus homilías llegaron a ser conocidas más allá de las fronteras de El Salvador hasta el punto de convertirlo en el más universal de los salvadoreños.

La comunicación que se establecía entre Monseñor Romero y su pueblo, y la influencia de las homilías en la vida de las personas e instituciones del país no tiene precedente alguno en la Iglesia y en la sociedad salvadoreñas. Hay que preguntarse, por lo tanto, ¿qué tenía aquella palabra que los pobres recibían como auténtica "buena noticia" y que ciertos grupos influyentes no soportaron hasta el punto de ordenar su asesinato ${ }^{3}, ?$ ¿Qué tienen las homilías de Monseñor Romero que tanto impacto 
causaron?

Lo que pretendemos hacer en este trabajo 4 es responder fundamentalmente a dos preguntas: la primera, más empírica, cómo predicaba en la realidad Monseñor Romero, y la segunda, más teórica, qué era para él la predicación homilética. Vamos a estudiar, pues, la estructura formal de sus homilías y la teología de la predicación que subyace en las mismas.

\section{Estructura formal de las homilías de Mon- señor Romero}

La estructura formal de las homilías de Monseñor Romero no es casual, sino que responde a una determinada teología de la predicación, de la que el principio más importante es que la palabra de Dios debe encarnarse en la realidad histórica de la comunidad eclesial. Hay dos momentos bien definidos en las homilías de Monseñor Romero: (a) la explicación de la palabra de Dios y (b) la encarnación de la palabra de Dios en la realidad histórica. A éstos debemos sumar otros dos momentos de no menor importancia: la introducción y la conclusión de la homilía. Si tomamos en cuenta todas las homilías de Mons. Romero, podemos sistematizar así la estructura formal de las mismas.

\section{Introducción:}

Saludo.

Contexto social de la homilía.

Contexto litúrgico.

Resumen de las homilías anteriores.

Definición de la homilía.

Explicación de la palabra de Dios:

Título de la homilía.

Enunciado de los tres pensamientos.

Desarrollo de los mismos.

Encarnación de la palabra de Dios en la realidad:

En la realidad eclesial:

-Iglesia local.

-Iglesia universal.

En la realidad política, económica, militar y social del país:

-Denuncias.

-Juicio de los hechos más importantes.

- Voz del pueblo organizado.
- Llamamientos a la conversión.

Conclusión:

Resumen doctrinal de la homilía.

Invitación a la liturgia eucarística.

En este esquema debemos tener en cuenta los aplausos 5 con que espontáneamente el pueblo respondía a su mensaje. Entre Monseñor Romero y su pueblo se establece una auténtica comunicación y diálogo. El pueblo escucha con atención, recibe con gozo las palabras de Monseñor Romero y le corresponde con el aplauso.

Esta es la estructura formal más completa que aparece sobre todo en sus últimas homilías. Ahora solamente vamos a comentar brevemente los dos momentos centrales de sus homilías.

\subsection{Explicación de la palabra de Dios}

Monseñor Romero comienza este momento de la predicación dando un título a la homilía. La homilía del 11 de septiembre de 1977 parece ser la primera que él mismo titula6. Esta costumbre se hace regular a partir de enero del siguiente año? En unos casos, los títulos que Monseñor Romero da a sus predicaciones son breves y reflejan el tema doctrinal que desarrollará; en otros, los uítulos, más extensos, son la formulación de la idea central que explicará. Si hacemos una lectura rápida de todos los títulos de las homilías de Monseñor Romero, constataremos cuáles son los temas más reiterados. A tenor de esto, podemos dividir las homilías de Monseñor Romero en dos grandes grupos: las homilias cristológicas y las homilias eclesiológicas. La Iglesia y el reino de Dios, por una parte, y Cristo y el proyecto de liberación cristiana, por otra, son los temas doctrinales más frecuentes de sus homilías.

Monseñor Romero siempre desarrolla el tema central de las homilías en tres pensamientos, los cuales enuncia de un modo conciso después de titular la homilía8. Estos pensamientos no siempre corresponden linealmente a las tres lecturas bíblicas de la liturgia; no es un pensamiento por cada lectura bíblica. De los múltiples temas que las lecturas de la liturgia pueden sugerir, Monseñor Romero elige uno, el más importante, que explaya en tres pensamientos con independencia de la lógica 
dada por las lecturas bíblicas.

La costumbre de titular y enunciar los tres pensamientos de la homilía revela algo muy importante: Monseñor Romero no improvisa su predicación. Monseñor Romero no leía sus homilías en el momento de la predicación, probablemente este esquema doctrinal fue el único material propio y escrito que Monseñor Romero tenía sobre el ambón a la hora de predicar; esquema que es fruto de una profunda meditación y planificación de sus homilías.

\subsection{Encarnación de la palabra de Dios en la realidad}

Monseñor Romero explicaba la palabra de Dios y aplicaba esta palabra a la realidad concreta de su Iglesia y de su país. Esta aplicación es quizá lo más característico y novedoso de sus homilías y era, sin duda, lo que los oyentes esperaban con más expectación. En este momento de la homilia, hay dos partes bien definidas: la aplicación de la palabra de Dios a la realidad eclesial y a la realidad política, económica y social del país.

En primer lugar, Monseñor Romero hace un minucioso recorrido de toda la actividad pastoral que él y toda la arquidiócesis han realizado durante la semana. Es así como lee las sencillas cartas del pueblo y agradece su apoyo, habla de sus visitas pastorales, se solidariza con los sacerdotes perseguidos, se hace eco de lo que las comunidades cristianas piensan, comunica resultados de reuniones pastorales, avisa e invita a actividades religiosas, comparte y corrige problemas pastorales. En ocasiones anuncia lo que sucede en la Iglesia universal y da a conocer los documentos y mensajes del magisterio latinoamericano y universal9. De tal manera que este momento de la homilía es como un noticiero. Así lo llamaba él mismol0.

En segundo lugar, Monseñor Romero dirigía su palabra hacia la realidad política, económica y social del país. Era el momento más esperado de la homilía. Era también el momento más conflictivo de su predicación.
Es aquí cuando Monseñor Romero ejerce el ministerio profético de la denuncia. Como se sabe, a Monseñor Romero le tocó vivir una etapa histórica muy convulsionada, la represión y la violación de los derechos humanos era "el pan amargo de cada día". Monseñor Romero no se limita a dar cifras de las violaciones de los derechos humanos, sino que nombraba, una a una, a las personas que eran objeto de la violencia, describía los tormentos que sufrían. En sus denuncias, Monseñor Romero era concreto y minucioso, ponía al descubierto la tremenda realidad de represión y muerte que sufría el pueblo. Muchas de las violaciones de los derechos humanos y asesinatos hubieran quedado en el anonimato si él no lo hubiera dado a conocer. Fue la voz de los pobres.

En este momento Monseñor Romero también enjuiciaba los hechos más importantes de la semana ya sea de carácter político, económico o militar. Monseñor Romero insistió en reiteradas ocasiones que su criterio de juicio no era político ni sociológico, sino teológico e histórico. El criterio para juzgar la realidad eran los pobres:

Según les vaya a ellos, al pueblo pobre, la Iglesia irá apoyando desde su especifidad de Iglesia, uno u otro proyecto político. O sea que la Iglesia así es como mira este momento de la homilía: apoyar aquello que beneficie al pobre, así como también denunciar todo aquello que sea un mal para el pueblo. Con este criterio vamos a juzgar algunos hechos de esta semana (17 de febrero de 1980, VIII p. 246) 11 .

En sus juicios sobre la realidad, Monseñor Romero era más analítico que descriptivo. En todas las coyunturas económicas, sociales o polfticas buscaba las causas del mal para proponer cambios estructurales y profundos.

Asimismo, dadas las graves restricciones a la libertad de expresión, Monseñor Romero se hace voz de las diferentes fuerzas sociales, especialmente de las organizaciones campesinas y de los sindicatos. No es raro encontrar en este momento de la homilía extensas lecturas de comunicados de

\section{La Iglesia y el reino de Dios, por una parte, y Cristo y el proyecto de liberación cristiana, por otra, son los temas doctrinales más frecuentes de sus homilías.}


asociaciones gremiales, de universidades o de organizaciones populares 12 . Monseñor Romero muestra especial interés por aquellos comunicados que ofrecen soluciones a los graves conflictos del país.

Monseñor Romero siempre une a la denuncia el llamamiento a la conversión y a las transformaciones estructurales de la sociedad salvadoreña. Estos llamamientos son una constante en las últimas homilías ${ }^{13}$, precisamente cuando la situación política se había tornado más crítica y grave. Monseñor Romero hace llamamientos a la oligarquía, al gobierno, a la Fuerza Armada y a los cuerpos de seguridad, al gobierno de Estados Unidos, a las organizaciones populares, a las organizaciones político militares y al pueblo no organizado. A cada sector dio una palabra oportuna y exigente. De todos estos llamamientos, el más conocido es el que dirigió en su última homilía al ejército y a los cuerpos de seguridad:

Yo quisiera hacer un llamamiento de manera especial a los hombres del ejército, y en concreto a las bases de la Guardia Nacional, de la Policía, de los cuarteles. Hermanos, son de nuestro mismo pueblo, matan a sus mismos hermanos campesinos y ante una orden de matar que dé un hombre, debe prevalecer la ley de Dios que dice: No matar. Ningún soldado está obligado a obedecer una orden contra la ley de Dios. Una ley inmoral, nadie tiene que cumplirla. Ya es tiempo de que recuperen su conciencia y que obedezcan antes a su conciencia que a la orden del pecado. La Iglesia, defensora de los derechos de Dios, de la ley de Dios, de la dignidad humana, de la persona, no puede quedarse callada ante tanta abominación. Queremos que el gobierno tome en serio que de nada sirven las reformas si van teñidas con tanta sangre. En nombre de Dios, pues, y en nombre de este sufrido pueblo cuyos lamentos suben hasta el cielo cada día más tumultuosos, les suplico, les ruego, les ordeno en nombre de Dios: ¡Cese la represión! (23 de marzo de 1980, VIII p. 382).

Resumiendo, podemos decir que en la estructura formal presentada hay momentos donde se acentúa lo doctrinal. Es el momento catequético de la homilía. Así le gustaba que lo reconocie- ran 14. Y Monseñor Romero fue un extraordinario catequista. Conceptos teológicos tan complejos y abstractos para un público poco acostumbrado a la reflexión teológica, como la trascendencia o la escatología, eran explicados por Monseñor Romero con una sencillez, claridad y novedad inigualables. Hay otros momentos de la homilía donde se subraya lo pastoral, sobre todo cuando Monseñor Romero hace la revisión del quehacer evangelizador de la semana. $\mathrm{Y}$ hay otro momento donde lo que destaca y predomina es lo profético.

En un brevísimo artículo sobre sus homilías, Gregorio Ruiz califica a Monseñor Romero como "el modelo más vivo de una predicación total"15. Por lo expuesto creo que no le falta razón a esta afirmación. La estructura formal de las homilías de Monseñor Romero es un modelo de predicación total: exégesis de la palabra de Dios y encarnación de la palabra de Dios en la realidad; catequesis doctrinal, exhortación pastoral y juicio de la realidad. Todo ello hace de la predicación de Monseñor Romero una predicación profética.

\section{Teología de la predicación de Monseñor Ro- mero}

A lo largo de sus casi 200 homilías dominicales Monseñor Romero explicitó, aunque no de un modo sistemático, una extensa y profunda teología de la predicación. El objetivo principal de este apartado es, precisamente, sisternatizar dicha teología. De Monseñor Romero podemos aprender que toda predicación para que sea verdaderamente cristiana ha de ser necesariamente una predicación profética.

La predicación ocupa un lugar primario en la vida de la Iglesia. Si la Iglesia existe para evangelizar, no es posible la evangelización sin la proclamación y explicación de la palabra. De tal manera que tanto en la predicación como en el quehacer pastoral la Iglesia realiza su identidad. Y esta palabra y este quehacer de la Iglesia han de ser necesariamente proféticos, en el sentido más estricto de la palabra, esto es, han de actualizar la palabra y la presencia de Dios en la historial6.

Analizando los textos donde Monseñor Romero habla explícitamente de la predicación, encon- 


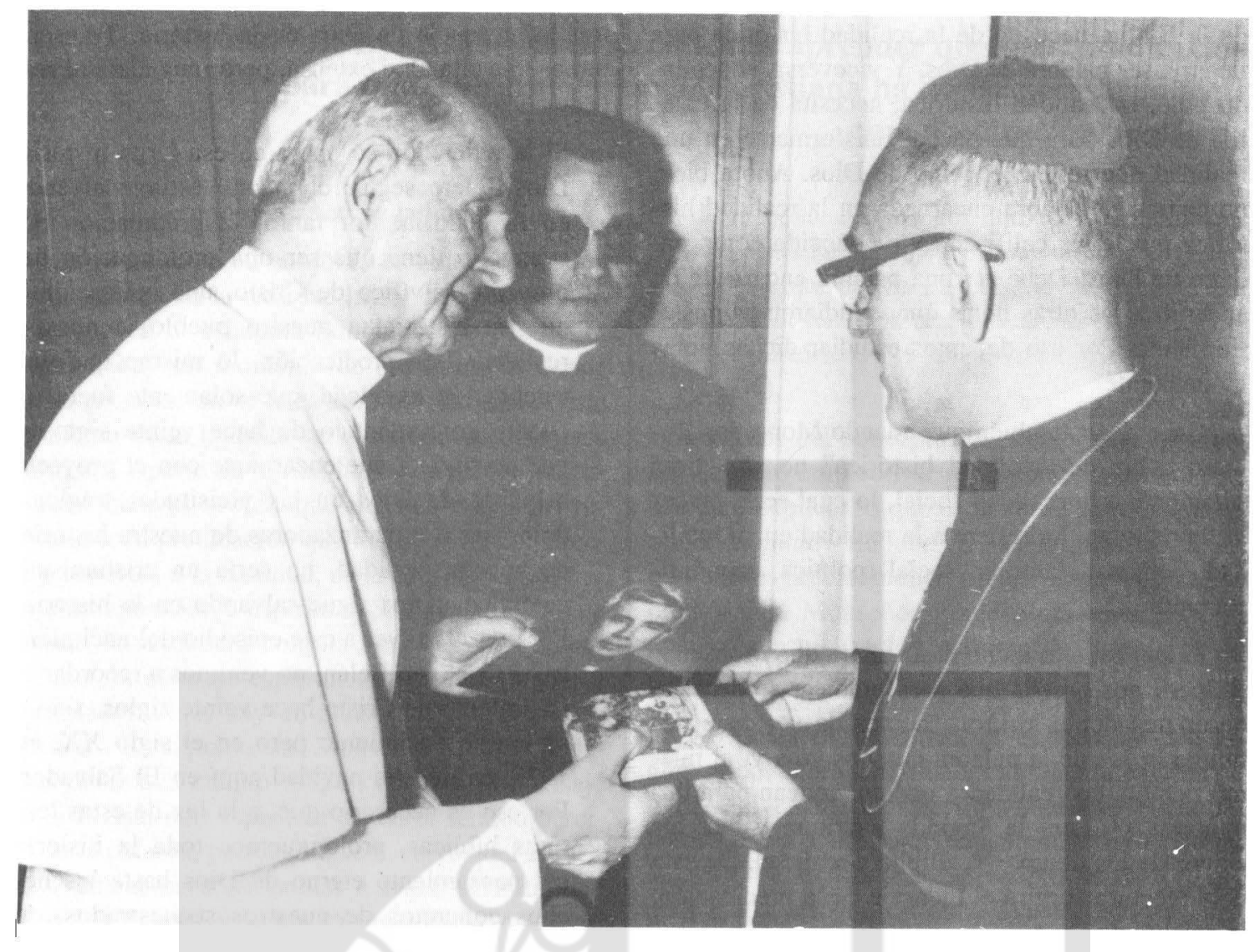

tramos siete notas que en su conjunto nos muestran qué es la predicación profética. La predicación profética es: (1) palabra encarnada en la realidad histórica; (2) palabra de Dios y palabra del pueblo pobre; (3) palabra eclesial; (4) palabra denunciante y esperanzadora; (5) palabra conflictiva; (6) palabra perseguida y (7) palabra libre y liberadora.

\subsection{Palabra encarnada en la realidad histórica}

La encarnación de la palabra de Dios en la realidad histórica "es lo que hace auténtica la predicación del evangelio"17. La misión del predicador consiste en unir el mensaje de la Sagrada Escritura con la realidad histórica:

No podemos segregar la palabra de Dios de la realidad histórica en que se pronuncia, porque no sería ya palabra de Dios, sería historia, sería libro piadoso, una biblia que es libro de nuestra biblioteca. Pero se hace palabra de Dios porque anima, ilumina, contrasta, repudia, alaba, lo que se está haciendo hoy en esta sociedad (27 de noviembre de 1977, III, p. 2).

Tenemos dos polos en la predicación cristiana: el mensaje de la Biblia y la realidad histórica. Ambos polos se necesitan para realizarse en plenitud. La expresión de Monseñor Romero puede parecer un tanto chocante, pues estamos acostumbrados a identificar sin más la Sagrada Escritura con la palabra de Dios, pero la Biblia sin encarnación en la realidad histórica actual no es palabra de Dios ${ }^{18}$, es "libro piadoso", un libro más de nuestra biblioteca. No es palabra de Dios que habla y nos dice algo hoy. La Biblia se hace palabra de Dios sólo en cuanto denuncia, orienta o anima el hoy de nuestra historia. La palabra escrita de la Biblia se hace palabra de Dios cuando es palabra proclamada y aplicada al hoy de nuestra historia en el acto de la predicación.

Es así como el primer polo, el mensaje escrito 
de la Biblia, necesita de la realidad histórica para llegar a ser palabra de Dios. Y viceversa, el segundo polo, la realidad histórica, necesita de la palabra de Dios para que pueda transformarse en una realidad que refleje el reino de Dios. Ahora bien, no cualquier palabra encarnada en la realidad histórica puede ser calificada y reconocida como palabra de Dios. Debe ser una palabra encarnada de acuerdo a las otras notas que estudiaremos posteriormente. Por eso debemos estudiar dichas notas globalmente.

Cabe decir también que cuando Monseñor Romero habla de "realidad histórica" no se refiere solamente a la realidad social, lo cual sería parcelar la realidad. Se refiere a la realidad en su totalidad: personal, familiar, social (política, económica, cultural).

Es por todo lo dicho hasta ahora que Monseñor Romero nos enseña que para predicar se necesita hacer una doble lectura: "hemos de ver cada domingo la luz de la palabra que nos guía y, al mismo tiempo, las realidades que nos rodean para iluminarlas"19. Leer la Sagrada Escritura y leer los signos de los tiempos20, Biblia y realidad. De esta doble lectura surgirá el mensaje de la predicación, la palabra de Dios.

El concepto teológico de encarnación es clave para comprender la teología de la predicación de Monseñor Romero. Es un concepto que utilizó en muchas ocasiones para explicar qué es la predicación. Podríamos hacer esta analogía: del mismo modo que no es posible la salvación sin la encarnación de Jesús; así también, no hay palabra de Dios, Dios no habla aquí y ahora, si no hay una encarnación de la Sagrada Escritura en la realidad histórica presente. Y así Monseñor Romero llegó a definir la predicación como "una prolongación del proyecto salvífico de Cristo"21.

Monseñor Romero nos enseñó con insistencia que "Dios habla desde la historia"22. De modo que la doble lectura, que decíamos antes, no hay que entenderla en un modo lineal y en una sola dirección, como si en la Sagrada Escritura estuviera la palabra de Dios y en la realidad histórica no hubiera nada de Dios y por eso necesita ser iluminada por aquélla. El objeto de la predicación es mos- trar la presencia de Dios en la historia. Transcribimos una cita algo extensa, pero muy clara al respecto:

Si la redención se opera en esa larga historia, Dios quiere seguir el mismo estilo: salvando en la historia. Por tanto, la predicación del evangelio tiene que ser una prolongación del proyecto salvífico de Cristo, una aplicación a nuestra historia, a nuestro pueblo, a nuestra realidad. Una predicación, lo mismo que una celebración navideña, que solamente fuera un cuentecito romántico de hace veinte siglos y que no tuviera que encarnarse con el proyecto salvífico de Dios en las vicisitudes trágicas, dolorosas o esperanzadoras de nuestra historia, de nuestra realidad, no sería un cristianismo auténtico. ¡Dios sigue salvando en la historia! Por eso, al volver a este episodio del nacimiento de Cristo en Belén, no venimos a recordar el nacimiento de Cristo hace veinte siglos, sino a vivir este nacimiento pero en el siglo $\mathrm{XX}$, en 1978, en nuestra navidad aquí en El Salvador. Por eso es necesario que, a la luz de estas lecturas bíblicas, prolonguemos toda la historia del pensamiento eterno de Dios hasta los hechos concretos de nuestros secuestrados, de nuestros torturados, de nuestra propia triste historia. Es allí donde tenemos que encontrar a nuestro Dios (24 de diciembre de 1978, VI p. 56).

La finalidad de la predicación no es, pues, tanto fijar la atención del oyente en la palabra de la escritura, como si allí fuera a encontrar la palabra de Dios, cuanto orientar al oyente, con la ayuda insustituible de la Sagrada Escritura, hacia la realidad histórica para que allí oiga al Dios que le habla desde la historia, desde lo positivo y lo negativo de la realidad.

Es por todo esto que cuando Monseñor Romero relata el quehacer pastoral de la comunidad, o lee los nombres de las personas asesinadas y desaparecidas, o hace un análisis de las causas de la injusticia social, o pronuncia un llamamiento al cese de la represión, no hace sino comunicar la palabra de Dios. En la predicación no podemos prescindir de la realidad histórica. Esto es lo que Monseñor Romero subrayó con más insistencia y 


\section{De Monseñor Romero podemos aprender que toda predicación para que sea verdaderamente cristiana ha de ser necesariamente una predicación profética.}

en ello radica su mayor aporte a la homilética.

La homilía en su conjunto es una encarnación de la palabra en la realidad histórica; pero ya dijimos que en el esquema homilético de Monseñor Romero hay un momento de sus homilías donde dicha encarnación se hace con más énfasis. A este momento de la homilía se le calificó de discursos políticos. Aparte de lo mal intencionada de la acusación, bien es sabido que muchos cristianos rechazan toda predicación que haga referencia directa y concreta a la realidad, se la califica de política en contraposición a espiritual. Según este modo de pensar, la verdadera homilía sería aquella que comunica un mensaje espiritual, eterno, orientador y consolador. Aquí hay un abuso del concepto "espiritual". En sintonía con Monseñor Romero podemos decir que cuanto más se encarna el mensaje de la Biblia, más espiritual es, en el sentido preciso de la palabra, por cuanto se hace voz del Espíritu. Predicar es dejar hablar a Dios, permitir que Dios hable aquí y ahora. $Y$ esto es lo que hizo Monseñor Romero. Lo contrario es apagar la voz del Espíritu o, lo que es peor, ocultar y tergiversar esa voz en un lenguaje pseudorreligioso.

No hay otro camino para dejar que Dios nos hable que "tocar" la realidad histórica. Leer un comunicado de las organizaciones populares, por ejemplo, en una homilía, ¿es salirse de los límites de una predicación? Monseñor Romero pensó que no. En una homilía, después de comentar los hechos de la semana, Monseñor Romero dice: "Al aludir a todo esto no nos hemos apartado de nuestra reflexión teológica y bíblica"23. Es precisamente este entrar en la realidad histórica lo que hace posible que Dios hable hoy, es lo que hace auténtica y cristiana la predicación. Monseñor Romero insiste en varias ocasiones que ello no significa salirse del evangelio, como tantas veces lo acusaron:

Los hechos históricos, si nosotros los enfocamos directamente, semana a semana, no es por un afán de salimos del evangelio y de la mente de la Iglesia, sino para que esa salvación que Dios está haciendo en los salvadoreños, encarnada en su propia historia, la busquemos allí donde la tenemos que buscar, en nuestros hechos históricos (19 de noviembre de 1978, V p. 304).

Además del concepto de encarnación, Monseñor Romero empleó frecuentemente otros dos verbos para explicar lo que es la predicación: actualizar e iluminar. En una de las últimas homilias, que tiene precisamente como tema central la predicación, Monseñor Romero define la homilía como "la actualización viviente de la palabra de Dios" 24.

No podemos universalizar el mensaje. De algún modo, la realidad histórica reta a la palabra de Dios. Universalizar puede equivaler a vaciar la palabra de Dios de contenido significativo. Como dice Monseñor Romero, la palabra de Dios "vale para todos pero no de igual manera, sino a cada uno según sus necesidades, sus circunstancias" 25. En otra ocasión afirma que aunque la palabra de Dios sea la misma:

No es lo mismo predicar este domingo trece en Roma, o en Polonia, o en Africa, o en Argentina, o en Nicaragua, que aquí en El Salvador. La palabra de Dios que hoy se acaba de proclamar es para nosotros, los salvadoreños de este domingo, 1 de julio de 1979. Tenemos que mirarlo desde esta perspectiva, el misterio de nuestra salvación, porque la historia de cada pueblo, de cada familia, es como el instrumento de Dios para salvar a ese hombre, a ese pueblo, a esa familia. Por eso, puede parecer muchas veces que la predicación toca cosas muy peligrosas y que sea más fácil callar, pero entonces no cumpliría la palabra evangélica su misión de iluminar en el misterio de Cristo la realidad del pueblo ( 1 de julio de 1979 , VII p. 40).

Aunque sea necesaria la exégesis y una 
exégesis bíblica seria, para una predicación, aquella no es suficiente26. Predicar no es únicamente hacer exégesis bŕblica. Predicar es actualizar. Así lo expresa Monseñor Romero: "La homilía, una palabra que significa el actualizar"27.

Actualizar significa que la palabra de Dios no es algo pasado, sino presente. Dios a través de su palabra actúa, se hace presente. Su palabra no es una palabra muerta, sino viva, operante, transformadora. Actualizar significa, por lo tanto, dos cosas: primero, hacer actual la palabra, trasladarla al presente, mediante la exégesis y la encarnación del mensaje en la realidad histórica. Y segundo, hacer actuante esa palabra, es decir, capaz de transformar la realidad histórica adversa al reino de Dios en una realidad que haga cercano el reino. Por eso Monseñor Romero relativiza la predicación, esto no es lo más importante, es sólo un camino; lo principal es celebrar y llevar esa palabra al compromiso, a la acción. Predicamos, celebramos y realizamos la palabra de Dios. Este es el ciclo completo de la predicación28.

Así como la catequesis nos ayuda a dar razón de nuestra fe, la predicación nos debe conducir a practicar la fe. Una predicación que da razón de nuestra fe y esperanza pero que no nos mueve a la práctica cristiana no es predicación, es simplemente catequesis, enseñanza. $Y$ debemos delimitar la diferencia entre catequesis y predicación. Es obvio que la predicación incluye la catequesis, pero no radica aquí su identidad. La identidad y la autenticidad de la predicación vienen dadas por el hecho de actualizar, o expresar cómo se está cumpliendo hoy esa palabra y cómo no se está cumpliendo y se debe cumplir. Predicar es decir, como Cristo, "estas cosas se han cumplido hoy" (Lc 4, 21). Esto supone que la comunidad eclesial que oye la predicación esté comprometida en una práctica cristiana de liberación. Solamente la comunidad que tiene un compromiso liberador está en la capacidad de comprender y hacer actuante la palabra liberadora de Dios.

Finalmente, el concepto que más emplea Monseñor Romero para explicar qué es la homilía es el verbo "iluminar":

El que predica en esta cátedra, como en todos los púlpitos de las iglesias, no hace otra cosa que ser un eco huinilde de esa voz divina $y$ orientadora: Cristo, el maestro. El que predica no hace otra cosa que tomar esa palabra eterna e iluminar con ella nuestras realidades, por donde va peregrinando nuestra historia. Por eso mi preocupación de traer como marco a la palabra de cada domingo, la historia de cada semana. Es una historia tan densa la de El Salvador, queridos hermanos, que nunca se agota. Cada domingo encontramos hechos que están pidiendo la luz de la palabra del Señor. Y el verdadero cristiano de El Salvador no puede prescindir de esas realidades, a no ser que quiera profesar un cristianismo aéreo, un cristianismo sin compromisos, espiritualista; y así es muy fácil ser cristiano, desencarnado, desentendido de las realidades que viven. Pero vivir ese evangelio, que por orden del Padre eterno tenemos que escuchar de Cristo - "A él escuchadle"-, vivirlo en el marco real de nuestra existencia, eso es lo difícil, eso es lo que crea conflictos, pero es lo que hace auténtica la predicación del evangelio y la vida de cada cristiano.

Cada uno de ustedes, queridos hermanos, tiene su propia historia, la historia de su propia familia. Sería imposible señalar aquí esas historias concretas, pero eso es trabajo íntimo de cada uno. Ilumine sus esperanzas, sus proyectos, sus desilusiones, sus fracasos, ilumínelos con la palabra de Dios para que viva siempre de fe y esperanza (19 de febrero de 1978, IV pp. 27-28).

La cita es extensa, pero recoge las ideas principales que repetirá en muchos otras homilías. Para Monseñor Romero, la predicación es una explicación sencilla de la palabra de Dios y una aplicación de la misma a la realidad 29 . Los hechos de la realidad histórica reclaman la luz de la palabra de Dios. Evadir estos hechos en la predicación es promover un cristianismo sin compromiso, "espiritualista". Esta iluminación de la realidad provoca conflictos, esto es inevitable, pero "es lo que hace auténtica la predicación del evangelio". La predicación no crea los males que hay en la realidad, sino que los pone al descubierto. "La luz 
ilumina lo que existe, no lo crea"30. Iluminar significa para Monseñor Romero poner al descubierto las injusticias del mundo y animar lo bueno que hay en la historia. Pero dado que la realidad es amplia y compleja y que la predicación está limitada, Monseñor Romero pide que cada cristiano ilumine su realidad personal y más próxima. Por eso, Monseñor Romero, en muchas ocasiones, más que iluminar cada hecho de la realidad, ofrece unos "principios iluminadores" 31 para que cada oyente, guiado por esos principios, ilumine, a su vez, su propia realidad.

\subsection{Palabra de Dios y palabra del pueblo pobre}

"Es que yo, que estoy hablando en este momento, soy la voz de Dios"32. Una atīrmación de tal categoría puede parecernos una presunción. En Monseñor Romero, sin embargo, no es una presunción, sino una verdad. No cualquier predicador puede afirmar lo mismo. Tal aseveración se entiende en el contexto de lo que hemos afirmado anteriomente: la Biblia se hace palabra de Dios cuando se encarna y actualiza en la realidad histórica. "Mi palabra no es mía sino palabra de Dios"33. "La palabra de hoy no es mía como nunca ha sido mi palabra, es la palabra de Dios que yo trato únicamente de comentar y aplicar a la realidad"34. Es precisamente en este comentar y aplicar a la realidad que la palabra de la Escritura se hace palabra de Dios.

Afirmar que lo escrito en la Biblia es palabra de Dios todos lo aceptamos; pero asegurar que el mensaje de un predicador es palabra de Dios no es tan aceptado ni fácil de comprender. Pero negar esto es negar la posibilidad de que Dios nos hable hoy a través de la palabra, como nos puede hablar también a través de los hechos históricos. Ahora bien, ¿cómo podemos verificar que una predicción es palabra de Dios? Puede suceder, como de hecho ocurre, que sea una palabra sobre Dios o un falseamiento de la palabra de Dios. Y aquí creo que reside otro de los aportes fundamentales y novedosos de la teología de la predicación de Monseñor Romero: la palabra del predicador es palabra de Dios en cuanto sea a la vez palabra del pueblo pobre. En la medida en que el predicador recoge y expresa el clamor del pueblo, la voz de los pobres, sus sufrimientos y aspiraciones, en esa misma medida, la palabra del predicador se agranda y se convierte en palabra de Dios.

Es en la homilía del 28 de agosto de 1977 donde hallamos por primera vez la formulación que después Monseñor Romero repetirá en varias ocasiones: "Queremos ser la voz de los que no tienen voz" 35 . Ser la voz del pueblo pobre supone dos pasos previos: uno, reconocer en la voz de los pobres la voz de Dios; y dos, escuchar y dialogar con el pueblo.

Cuando Monseñor Romero dice que "el pueblo es mi profeta" 36 está reconociendo que él escucha en la palabra del pueblo, en sus sufrimientos y justos reclamos, la palabra de Dios. Es Dios quien sufre y reclama. No se trata de reconocer las voces aisladas del pueblo, sino de reconocer el consenso. Cuando hay "consenso" en el pueblo - afirma Monseñor Romero -, "esto no puede ser otra cosa que la palabra de Dios que habla, Cristo que vive en su pueblo" 37 . Ciertamente, en las muchedumbres silenciadas y oprimidas hay un "consenso" de sufrimiento que el predicador no puede pasar por alto, así como también en una voz de un sector del pueblo pueden estar expresadas las aspiraciones de

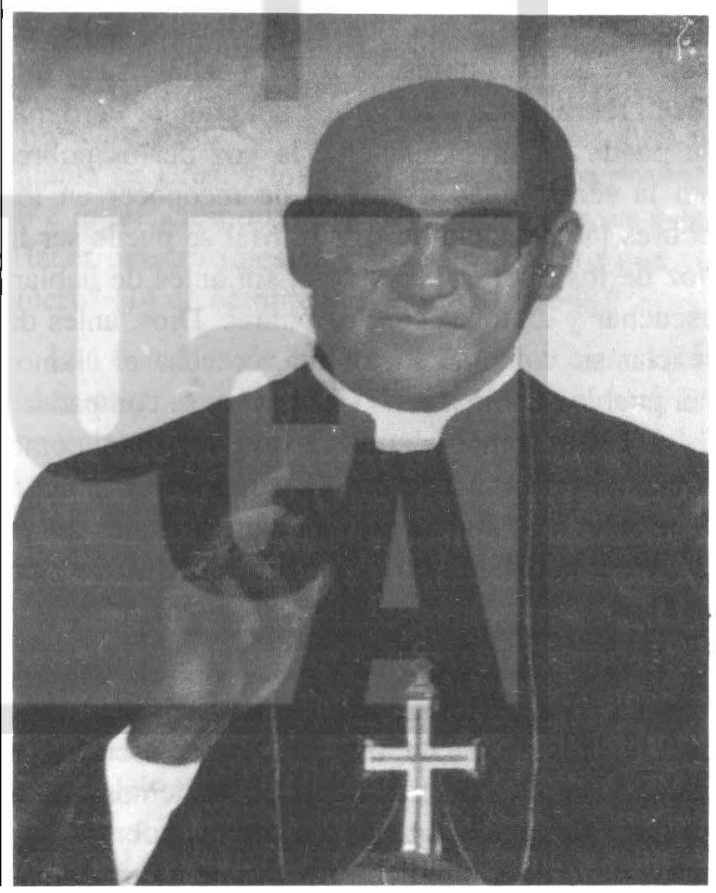


todo el pueblo. Monseñor Romero reconoce en la miseria y en los sufrimientos del pueblo pobre la presencia de Cristo. La cita de Mateo 25, 31-46 es muy frecuente en sus homilías. Para Monseñor Romero, la pobreza es una denuncia divina, un espíritu y un compromiso38.

Ahora bien, este reconocimiento debe ser mutuo. También el pueblo debe reconocer en la voz del predicador la verdad de la palabra de Dios. Es interesante comprobar que Monseñor Romero no pone como criterio de la autenticidad de un predicador solamente la fidelidad a la palabra de Dios y al magisterio de la Iglesia. Monseñor Romero añade otro criterio no menos importante y que suele ser silenciado: el pueblo de Dios. El pueblo de Dios es garantía también para asegurarle al predicador que su doctrina, su enseñanza, va por los caminos de la verdadera revelación (2 de julio de 1978, V p. 47). El rechazo o la aceptación del pueblo de Dios es fundamental para verificar si la predicación es efectivamente palabra de Dios y palabra del pueblo pobre 39.

Por ello, la primera actitud del predicador no es hablar, sino escuchar: "Yo tengo que escuchar qué dice el Espíritu por medio de su pueblo" 40 . "Yo también, hermanos, recibo la predicación de ustedes 4 1". No basta que el predicador hable en nombre de los pobres; se oyen muchas voces que dicen representar y ser la voz del pueblo. Pero mal se puede ser cristianamente la voz de los pobres sin la sensibilidad espiritual de reconocer en los pobres la presencia de Cristo. Mal se puede ser la voz de los que no tienen voz, sin antes de hablar, escuchar y dialogar con los pobres. Dios, antes de revelar su voluntad liberadora, escucha el clamor del pueblo (Cfr. Ex 3,7). Jesús ve y se compadece de aquellas muchedumbres que vagaban como ovejas sin pastor (Mc 6, 34). Escuchar y compadecerse son actitudes previas sin las cuales no es posible una palabra que sea buena noticia, que sea de Dios.

Hemos visto hasta ahora las actitudes previas para ser voz de los pobres: reconocer en los pobres la presencia y la voz de Dios; y escuchar y dialogar con el pueblo pobre. Estudiemos ahora qué significa realmente ser voz de los pobres. Significa dos cosas: predicar efectivamente en defen- sa de los pobres y comunicar explícitamente la voluntad de los pobres.

Cuando Cristo anuncia que ha venido a dar buenas noticias a los pobres (Lc 4, 18), marca la pauta de lo que debe ser la verdadera predicación. Dar buenas noticias a los pobres, a aquellos que - como dice Monseñor Romero- están acostumbrados a recibir malas noticias 42 . Los pobres se constituyen en el criterio último para enjuiciar la realidad43 y también en el único "lugar" posible para comprender la palabra de Dios44. Cuando Monseñor Romero es amenazado a muerte reafirma su compromiso de seguir predicando en defensa del pueblo45. Esta opción por los pobres traerá consigo el conflicto y el rechazo de los poderosos. Ser la voz de los que no tienen voz "cae mal a aquellos que tienen demasiada voz" 46 .

Monseñor Romero afirma que jamás ha parcializado su voz, pero sí se ha puesto con "compasión de Cristo al lado del muerto, de la víctima, del que sufre" 47 . Monseñor Romero no fue partidista, pero sí fue parcial. El no se puso al lado de una organización del pueblo en particular, sino al lado de las mayorías pobres, de aquellos que no tienen voz, que tal vez ni siquiera están organizados, que llevan sobre sus espaldas las más pesadas cargas del dolor y de la muerte. Y se sitúa al lado de ellos con "compasión de Cristo". Esto es importante subrayarlo. No hay un interés previo, no hay una finalidad determinada, es solamente compasión de Cristo. Asimismo, la parcialidad evangélica de Monseñor Romero hacia los pobres no es una parcialidad sin crítica. En cierta ocasión afirma que no hay que tenerle miedo a quedarse solo, a sentir incluso la incomprensión del mismo pueblo y por querer contentar al pueblo callar 48 . Monseñor Romero rechaza todo asomo de demagogia. Y esto es precisamente lo que dio credibilidad y autoridad a su palabra. Si la predicación de Monseñor Romero hubiera sido partidista no cabe la menor duda que no hubiera tenido la resonancia que tuvo, no hubiera sido una palabra reconocida por el pueblo pobre como palabra de Dios.

Monseñor Romero dejó bien claro que la Iglesia debe hacer una clara e ineludible opción por los pobres. Y nos explicó en muchas ocasiones qué es la opción por los pobres. Para profundizar 
en ello es recomendable leer las siguientes homilías: "En Cristo se revelan las tres dimensiones de los verdaderos grandes" 49 , "Las tres condiciones para entrar en el reino de Dios"50, "Las tres fuerzas cristianas que forjarán la liberación de nuestro pueblo" 51 , y "La pobreza de las bienaventuranzas, fuerza de la verdadera liberación del pueblo"52.

Ser la voz de los pobres significa, también, "expresar" el clamor del pueblo oprimido, "hacer oír" esa voz del pueblo que se quiere silenciar. Y esto hay que entenderlo dentro de la dinámica profética. Lo que se pretende, al expresar la voz del pueblo pobre, es corregir el mal que hace clamar al pueblo: "Es por tanto, como pastor, que yo expreso, con ánimo de corregir, el clamor del pueblo oprimido por el pecado y la injusticia del mundo"53. Aquí el predicador no es una voz aislada, es portavoz del pueblo profético54. Expresar el clamor del pueblo es revelar la palabra de Dios que se manifiesta en ese clamor. No es un mero dar a conocer lo que el pueblo sufre o lo que el pueblo piensa, aunque sea también eso, para despertar la condolencia y la caridad; es más, es hacer sentir en el clamor del pueblo la tremenda voz de Dios que está hablando, que habla hoy, para corregir desde la raíz el pecado del mundo, el pecado que trae la muerte a los pobres. Expresar el clamor del pueblo es también afirmar que no es posible quitar el pecado del mundo, sino es desde la perspectiva de los pobres.

Si Monseñor Romero lee las cartas de los pobres en sus homilías, si da a conocer sus reivindicaciones justas, si en sus predicaciones lee los comunicados de las organizaciones populares es porque "ésta es la voz que no se oye y a la que noso-

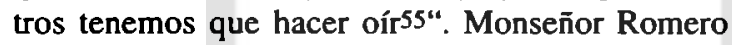
reconoce que en esto la Iglesia está cumpliendo un papel supletorio56. Debe ser el mismo pueblo quien exprese sus derechos y reivindicaciones.

Sin embargo, cuando la libertad de expresión es reprimida con sangre, la Iglesia está obligada a asumir ese papel. Según esto pudiera pensarse que no habiendo restricciones a la libertad de expresión, la Iglesia ya no tiene por qué ejercer su misión profética, sino que debe entonces subrayar su misión doctrinal. Ciertamente, la Iglesia podrá dejar de ser el medio por el cual el pueblo pobre se comunica, porque el pueblo ya se comunica por sus propios medios. Pero no significa esto que la Iglesia ya no tendrá una palabra profética que decir. Ser la voz de los sin voz tiene tres dimensiones: una dimensión evangelizadora, dar buenas noticias a los pobres, porque sólo desde los pobres y con los pobres se puede expresar y comprender la palabra liberadora de Dios; una dimensión profética, porque sólo desde los pobres se puede corregir desde la raíz el pecado del mundo; y una dimensión comunicadora, dar a conocer lo que los pobres reclaman cuando éstos no tienen otros medios de comunicación. Que esta última ya no sea necesaria no significa que las otras dos dimensiones tampoco sean necesarias. Dar la buena noticia a los pobres y ser voz del pueblo profético son condiciones de la verdadera predicación que bajo ninguna circunstancia pueden desaparecer de ella. El predicador, sea la coyuntura histórica que sea, mientras haya pecado en el mundo y un pecado que acarrea la muerte de los pobres, siempre tendrá una palabra profética que decir, una buena nueva que comunicar. La Iglesia - dice Monseñor Romero- "no dejará de ser voz de los que no tienen voz mientras haya oprimidos" 57 .

\subsection{Palabra eclesial}

El objetivo más inmediato de la predicación ha de ser construir la Iglesia, así nos lo recuerda Monseñor Romero: "Mi sueño al predicar aquí la palabra de Dios, y mi agradecimiento más profundo a la atención que ustedes le dispensan, es éste: ¡Hacer nuestra Iglesia! Esto es lo primero que yo quiero" (14 de octubre de 1979, VII p. 348).

Las homilías de Monseñor Romero están dirigidas, en primer lugar, a la comunidad eclesial. Es una palabra que busca construir la verdadera Iglesia de Jesucristo, la Iglesia de los pobres58. Ya hemos dicho que la Iglesia era uno de los temas preferidos de Monseñor Romero en sus homilías.

La homilía es palabra eclesial porque su finalidad primera es edificar la comunidad de los creyentes. No es una finalidad cerrada, se construye la comunidad eclesial para que sea fermento en el mundo del reino de Dios. Hacer el reino de Dios, que es gracia y tarea, es el contenido y la finalidad última de la predicación cristiana59. El objetivo de 
la predicación no puede ser otro que el de Jesús: el reino de Dios. Es el anuncio y la realización del reino de Dios en la historia de los hombres, reino de Dios que va más allá de los límites de la Iglesia.

La eclesialidad de la palabra del predicador significa también que éste no es una voz aislada. Si hemos dicho que el predicador habla o debe hablar en nombre de Dios y en nombre del pueblo pobre, también es cierto que debe hablar en nombre de la Iglesia. De hecho, cuando el celebrante predica es toda la Iglesia la que predica. Monseñor Romero concebía sus homilías como la voz de toda la arquidiócesis:

Aunque yo sólo sea el que habla, es como la boca de un organismo. La boca habla pero su palabra compromete a todo el cuerpo. Es todo el individuo el que está hablando por esa palabra. Aquellos que quieren aislar al arzobispo del resto de los sacerdotes o de los fieles están muy equivocados. ¡Cómo quisieran estar oyendo una boca sin organismo! ( 2 de abril de 1978, IV p. 128).

Ahora bien, la eclesialidad de la predicación no es cuestión intencional. La predicación será efectivamente palabra de la Iglesia en la medida que esté en comunión con Cristo, con el magisterio de la Iglesia y con el pueblo de Dios.

En comunión con Cristo. Monseñor Romero definió la Iglesia como "la prolongación siempre actual y operante de Jesús"60. Jesús predica hoy mediante su Iglesia. La Iglesia será auténtica mediación de la palabra de Jesús si efectivamente es buena noticia para los pobres. Es importante acentuar que la eclesialidad de la palabra del predicador no viene garantizada solamente por su comunión con la jerarquía de la Iglesia —que es lo que más se subraya-, sino por su comunión con la buena noticia para los pobres de Jesús. La homilía ha de ser realmente la prolongación de la homilía que Cristo inició en Nazaret61. La homilía del predicador no es palabra de la Iglesia, si no es palabra de Cristo. Esto que parece evidente no lo es tanto cuando se dan conflictos intraeclesiales por causa de la predicación.

En comunión con el magisterio de la Iglesia. "Todo aquel que predica en la tierra" -decía Monseñor Romero- "tiene que confrontar su predicación con la predicación del sucesor de Pedro"62. Para predicar es necesario poseer la vocación, ser llamado por Dios, tanto más cuanto que el que predica no habla con voz propia, es portavoz de Dios. Pero esto no es suficiente, además ha de poseer una "comprobación jerárquica que nos una al magisterio autorizado de la Iglesia"63. La palabra del predicador no puede ser una voz disonante y opuesta al magisterio de la Iglesia. Ahora bien, la verdadera comunión eclesial no procede de una adhesión verbal al magisterio de la Iglesia, sino de la encarnación de la doctrina de la Iglesia universal en la Iglesia particular del que predica. Y es aquí donde surge el conflicto:

Es fácil predicar teóricamente una enseñanza. Seguir fielmente el magisterio del Papa en teoría es muy fácil. Pero cuando se trata de vivir, cuando se trata de encarnar, cuando se trata de hacer realidad en la historia de un pueblo sufrido como el nuestro esas enseñanzas salvadoras, es cuando surgen los conflictos ( 2 de julio de 1978, V p. 42).

Las homilías de Monseñor Romero son un ejemplo claro de esta encarnación del magisterio de la Iglesia en la realidad nacional y eclesial. No hay homilía donde Monseñor Romero no cite textualmente al magisterio eclesial. Textos de los documentos del Vaticano II $-\mathrm{y}$ dentro de éstos la constitución dogmática Lumen Gentium y la constitución pastoral Gaudium et spes-, Medellín y Puebla son muy frecuentes en las predicaciones de Monseñor Romero. Hay casos, como en la misa exequial del P. Rutilio Grande, donde el guión y la exposición de la homilía no se construyen a partir de las lecturas bíblicas, sino a partir del número 38 de la Evangelii Nuntiandi64. Cuando Monseñor Romero expone el magisterio de la Iglesia no lo hace teóricamente, su intención no es solamente

\section{En esto radica la comunión jerárquica del predicador: en encarnar el magisterio de la Iglesia en la realidad concreta donde predica.}


dar a conocer, sino "hacer sangre y vida, verdad e historia... la doctrina de los concilios y de los papas"65. El magisterio de la Iglesia alcanza la plenitud de la verdad en cuanto deja de ser palabra escrita para ser palabra realizada en la historia de los pueblos y de la Iglesia. De ahí el énfasis que Monseñor Romero pone en lo que él llamaba el noticiero. No debemos considerarlo como un cuerpo extraño de la homilía o como algo accidental. Al dar noticias de carácter eclesial, Monseñor Romero quiere mostrar hasta qué punto la Iglesia local hace "verdad e historia" el magisterio de la Iglesia:

Por eso, para quienes no están acostumbrados a oír nuestras homilías les diré que pasamos aquí una especie de crónica de nuestra semana para decirles lo que trabajamos en la Iglesia, no por vanidad sino con el afán de compartir con todos los que creemos en el Señor y formamos la Iglesia los ideales en los cuales queremos crecer cada día más para hacer verdadera Iglesia de Jesucristo (2 de marzo de 1980, VIII p. 297).

Monseñor Romero dio a conocer más que nadie la doctrina del magisterio de la Iglesia. En sus explicaciones y aplicaciones de los documentos de la Iglesia, éstos adquirían una verdad y una claridad inigualables. Textos de difícil comprensión, por el lenguaje "oficial" que caracteriza a los documentos del magisterio eclesial, eran expuestos con sencillez y claridad. Textos que por su universalidad podrían pasar inadvertidos al ser encarnados en la realidad salvadoreña, adquirían un acento profético. En las homilías de Monseñor Romero, el magisterio de la Iglesia adquiría verdad y credibilidad.

En esto radica la comunión jerárquica del predicador: en encarnar el magisterio de la Iglesia en la realidad concreta donde predica. La palabra del predicador es palabra eclesial cuando hace "verdad e historia" el magisterio de la Iglesia. La adhesión intencional del predicador con la jerarquía o la fidelidad verbal en la exposición del magisterio no son suficientes. La homilía se hace palabra de la Iglesia cuando encarna su enseñanza en la realidad histórica. Todo lo que expusimos sobre la encarnación de la palabra de Dios en la realidad es válido para comprender lo que debe ser la encarnación del magisterio de la Iglesia.

En comunión con el pueblo de Dios. Este factor de la comunión eclesial es quizá el más olvidado o el más silenciado. La predicación es voz de la Iglesia, palabra eclesial, cuando está en comunión no sólo con la jerarquía, sino con todo el cuerpo de la Iglesia, el pueblo de Dios. Así como las mayorías pobres son el criterio último y fundamental para juzgar proféticamente la realidad, el pueblo de Dios es también criterio para juzgar la autenticidad o la falsedad de la predicación. En las últimas homilías de Monseñor Romero se observa un esfuerzo por delimitar las coincidencias y diferencias entre el pueblo y el pueblo de Dios66. Monseñor Romero quiso dejar bien claro que no se puede identificar sin más al pueblo con el pueblo de Dios:

Yo quiero insistir, queridos hermanos, en una distinción que debe estar en nuestro tiempo muy bien clarificada. No es lo mismo decir el pueblo que decir el pueblo de Dios. ¿Qué diferencia hay? El pueblo es todo lo que habita la patria. Todo ése es el pueblo salvadoreño, incluyendo los que no creen, los indiferentes.

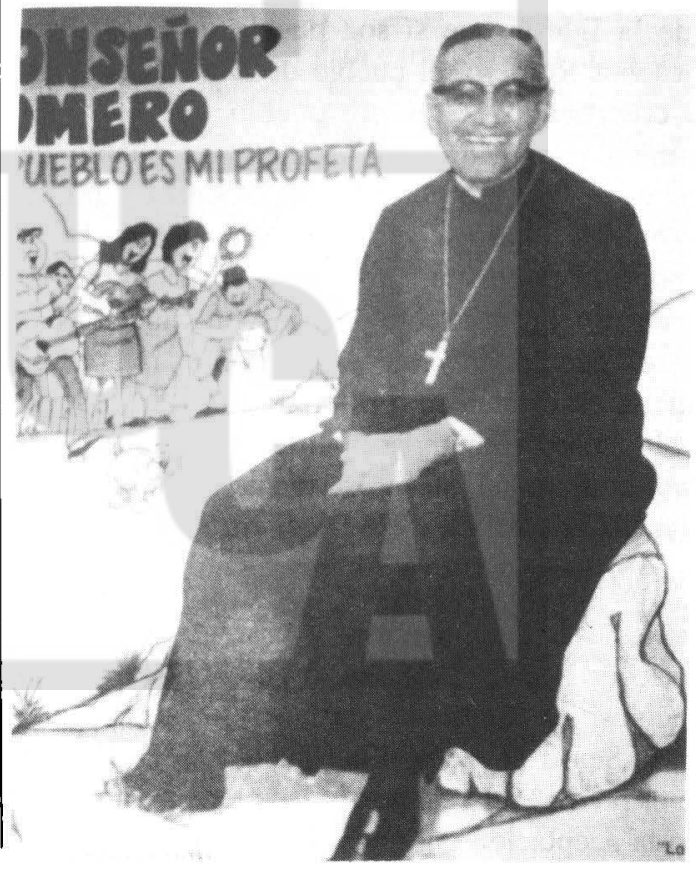


Todos aquellos, crean o no crean, son el pueblo. Pero cuando decimos el pueblo de Dios queremos decir la comunidad cristiana entre los salvadoreños, aquellos que han recibido el mensaje de Cristo, que se han convertido y, para manifestar esa conversión, se han bautizado y están preparando, como decía Juan Bautista, un pueblo perfecto para la venida del Señor. De allí que el pueblo de Dios es una selección. No lo decimos con orgullo ni soberbia, porque tal vez nosotros no somos el pueblo de Dios cuando no estamos convertidos de verdad. Pueblo de Dios también es, aún fuera de las fronteras de la Iglesia, todos aquellos que no han conocido a Cristo pero han puesto en Dios su esperanza y su confianza. Por eso podemos decir: no están todos los que son ni son todos los que están (9 de diciembre de 1979 , VIII pp. 19-20).

Pueblo de Dios es, por lo tanto, el pueblo de los bautizados que están "convertidos de verdad", pero el pueblo de Dios va más allá de las fronteras de la Iglesia. También forman parte del pueblo de Dios los que "no han conocido a Cristo pero han puesto en Dios su esperanza". Hay muchos dentro de la Iglesia que no son pueblo de Dios porque no viven en proceso de conversión y hay muchos fuera de la Iglesia que sí son pueblo de Dios. Para Monseñor Romero, el pueblo de Dios es el "pueblo crucificado"67, es el "pueblo que sufre"68. También para Monseñor Romero, el pueblo de Dios es el "pueblo profético"69. Pobreza y profecía son dos notas esenciales en el pueblo de Dios. La pobreza es el elemento que identifica al pueblo en general con el pueblo de Dios; en América Latina, el pueblo creyente es el pueblo pobre. La profecía es el elemento diferenciador; no todo el pueblo, como comunidad política, vive en conversión y comunidad, siendo fermento en la sociedad de los valores del reino de Dios.

Este pueblo crucificado por la injusticia y la miseria, este pueblo pobre y profético es, según Monseñor Romero, el criterio que asegura al predicador si su palabra es verdadera o falsa revelación70. Sentir el rechazo del pueblo de Dios es lo que el predicador realmente debe temer. El rechazo o la aceptación del pueblo de Dios a la palabra de la predicación es lo que en realidad y en última instancia prueba la verdad o la falsedad de dicha palabra. Generalmente se pone el acento no tanto en el pueblo de Dios, pobre y crucificado, cuanto en la jerarquía. Si bien, el Papa y los obispos tienen la misión de salvaguardar la integridad de la verdad revelada, a la hora de juzgar si tal predicación responde a la revelación de Dios han de escuchar al pueblo de Dios, han de comprobar cuál es la actitud del pueblo de Dios ante esa palabra; si con esa palabra el pueblo deja la indiferencia y se convierte realmente en pueblo de Dios, en un pueblo que fermenta la sociedad y construye el reino. Si es así, aquella palabra está cumpliendo las virtualidades de la revelación, es una palabra verdadera. En virtud de esto, el pueblo de Dios puede detectar cuando un predicador está o no en sintonía con la verdad revelada:

Porque yo también, hermanos, recibo la predicación de ustedes. Yo sé, con la doctrina teológica de la Iglesia, que ese don de la infalibilidad, que sólo Dios posee, lo ha dado al pueblo de Dios, y que ese pueblo de Dios tiene un órgano que es el Papa; el Papa expresa el carisma de la infalibilidad al mismo tiempo que el pueblo lo siente y lo vive. Por eso el pueblo sabe sentir cuándo la predicación no es auténtica. Ustedes tienen un sentido muy fino que se llama el sensus fidei, sentido de fe, por el cual un miembro del pueblo de Dios puede detectar cuándo un predicador no está a tono con la doctrina verdaderamente revelada por Dios (2 de julio de 1978, V pp. 46-47).

Los pobres acogieron y aceptaron la palabra de Monseñor Romero, los ricos y poderosos la rechazaron y la silenciaron. Esta es una señal inequívoca de la eclesialidad de sus homilías. El pueblo pobre y crucificado, con sentido de fe, supo captar en las homilías de Monseñor Romero el paso de un Dios que habla hoy. El notable impulso y la vitalidad de la arquidiócesis en aquellos años no dan cabida a la duda.

Finalmente, mal se puede "construir Iglesia" si la predicación no ejerce la profecía hacia su interior. Y ésta es otra de las características que definen la eclesialidad de la predicación. "La palabra de Dios cuestiona al primer destinatario que es la 
Iglesia"71. La Iglesia es santa y pecadora. Necesita la conversión para ser verdadera Iglesia, sacramento de salvación 72 . La Iglesia necesita profetas que señalen con audacia y libertad sus pecados:

El profeta también denuncia los pecados internos de la Iglesia. ¿Y por qué no? Si obispos, papas, sacerdotes, nuncios, religiosas, colegios católicos, estamos formados por hombres y (los) hombres somos pecadores y necesitamos que alguien nos sirva de profeta también a nosotros para que nos llame a conversión, para que no nos deje instalar una religión como si ya fuera intocable. La religión necesita profetas y gracias a Dios que los tenemos, porque sería muy triste una Iglesia que se sintiera tan dueña de la verdad que rechazara todo lo demás. Una Iglesia que sólo condena, una Iglesia que sólo mira el pecado en los otros y no mira la viga que lleva en el suyo, no es la auténtica Iglesia de Cristo (8 de julio de 1979, VII pp. 62-63).

Es importante subrayar la importancia de la denuncia profética en el interior de la Iglesia; sin ella, la Iglesia corre el peligro de instalarse en una falsa seguridad y de acomodarse junto a los poderes del mundo. Asimismo, la predicación de la Iglesia que no denuncia y corrige sus pecados es una predicación que pierde credibilidad y verdad. Monseñor Romero lleva hasta el extremo su argumento: la Iglesia que no ve y corrige sus propios pecados "no es auténtica Iglesia de Cristo". Es obvio que esta denuncia no se hace con el ánimo de desprestigiar a la Iglesia. La finalidad de la denuncia profética es siempre la conversión. La fidelidad a la Iglesia no se demuestra callando sus pecados, sino señalándolos para corregirlos, para construir verdaderamente la Iglesia:

Esta fidelidad a la Iglesia yo puedo constatarla. Una fidelidad que se inspira en el evangelio y desde el evangelio tiene la audacia de denunciar los pecados mismos de la Iglesia, porque lo que interesa es que esta Iglesia sea fiel a Jesucristo, y en ella la voz de los que quieren ser fieles a Jesucristo tendrá que encontrar muchas veces algo que decir a los mismos miembros de la Iglesia (21 de junio de 1979, VII p. 11).
En las homilías de Monseñor Romero son frecuentes las denuncias de los pecados de la Iglesia, especialmente las denuncias contra la división de la jerarquía 73, la actitud de muchos cristianos que han pasado a ser enemigos y perseguidores de la Iglesia, el abuso y la "comercialización" de los sacramentos que algunos sacerdotes promueven haciendo de la religión un "negocio"74, el miedo y la falsa prudencia de algunas instituciones cristianas que no quieren aportar desde su fe y carisma a los graves problemas del país75, etc. Monseñor Romero hace estas denuncias porque en verdad quiere construir la Iglesia, quiere congregarla en una unidad sólida y no aparente. En él, la Iglesia institución y la Iglesia profecía entraron en una tensión enriquecedora. Las denuncias intraeclesiales de Monseñor Romero no socavaron lo institucional de la Iglesia, sino que lo colocaron en función de su misión.

Lo importante ahora es subrayar que, siendo la construcción de la Iglesia, y por consiguiente su permanente conversión, la finalidad primera e inmediata de la homilía, no se puede calificar sin más de eclesial la predicación que sistemáticamente omite la denuncia intraeclesial.

\subsection{Palabra denunciante y esperanzadora 76}

Para comprender esta característica de la teología de la predicación han de tenerse en cuenta especialmente estas dos homilías: "El profeta, presencia de Dios en la sociedad"77 y "Cristo nos ha confiado una misión profética"78. Pero la mejor sistematización de lo que significa una predicación denunciante y esperanzadora nos la ofrece el mismo Mons. Romero en la homilía del 30 de octubre de 1977:

El pastor tiene que estar donde está el sufrimiento. $Y$ yo he venido, como he ido a todos los lugares donde hay dolor y muerte, a llevar la palabra de consuelo para los que sufren, expresar la condolencia a la familia doliente... También quise que fuera una palabra de repudio al crimen, repudio a la violencia. ¿Cuándo vamos a terminar esta ola de sangre y de tormento para nuestra patria? También quise que fuera mi palabra en ese funeral una palabra de apoyo a los reclamos justos de nuestro pueblo. 


\section{El rechazo de la predicación llega hasta el extremo de la persecución y la muerte de los predicadores.}

Los reclamos justos, les decía yo, ¿qué pecado hay en que un pobre cortador de café o de caña o de algodón con hambre pida ocho cucharadas de sopa, un huevo, una comida que apenas le reponga las energías que gasta, para ayudar a levantar esas cosechas que hacen feliz al país, que debe ser obra de Dios para felicidad de todos?... Y como pastor, en nombre de Dios que crea las cosas, digo a los que trabajan y a los gobernantes que sean justos, que escuchen el clamor del pueblo, que con sangre y con violencia no se van a arreglar las situaciones económicas, sociales y políticas... Y finalmente, yo dije frente al cadáver de José Roberto, la Iglesia no puede callar aquí una palabra de esperanza, una palabra del más allá, la lucha reivindicadora de los derechos de la tierra no debe olvidar que hay un Dios que juzga (30 de octubre de 1977, I-II pp. 296-297).

En esta cita encontramos cuatro notas que definen a la predicación como palabra denunciante y esperanzadora.

Primera nota. Palabra de consuelo. La palabra profética está transida de humanidad. Es una palabra que parte de la razón y del corazón. No expresa fríamente lo que la inteligencia capta, sino que además comunica lo que el corazón siente. Es una palabra que nace de ver la realidad con entrañas de misericordia, por eso es una palabra humana y cercana, una palabra que consuela al que sufre, al que ha sido privado de su dignidad de persona. Pero para que esta palabra sea posible, el predicador "tiene que estar donde está el sufrimiento". Monseñor Romero en sus homilías y en sus visitas pastorales 79 acompañó a los pobres. Llevó una palabra de consuelo a los que sufren y dio sentido a este sufrimiento; no un sentido adormecedor, sino liberador 80 .

Segunda nota. Palabra de repudio al crimen. "Este es el pensamiento fundamental de la predicación: nada me importa tanto como la vida humana"81. Nada le importó tanto a Monseñor Romero como la vida humana y en especial la vida de los más indefensos, los pobres. De ahí el repudio y la condena de todo lo que amenaza la vida. El profeta es el defensor del bien supremo de la vida. El repudio de la violencia fue claro y taxativo en Monseñor Romero. Pero también fue analítico, no se conformó con condenar los efectos, sino también las causas de la violencia: las injusticias sociales, la violencia institucional 82 .

Tercera nota. Palabra de apoyo a los reclamos justos del pueblo. Y con la misma fuerza y claridad con que condena el pecado estructural que acarrea la muerte, Monseñor Romero apoya aquello que trae vida y alegría para los pobres. Aunque Monseñor Romero insistió que no se confundiera su voz con otras voces, tampoco por eso desistió de apoyar las reivindicaciones justas del pueblo. Indudablemente, si esto se hace, se corre el peligro de ser confundido con otras voces del campo político, con las voces de las organizaciones populares. Monseñor Romero temía más que su palabra fuese manipulada por los sectores de derecha que confundida con otras voces de la izquierda. Que su palabra de apoyo a los pobres fuese confundida con otras voces del pueblo es un mal menor frente al mal mayor de ser manipulada por las fuerzas opresoras que harían de esa palabra una palabra de muerte.

Sin embargo, el apoyo de Monseñor Romero a las organizaciones populares fue claro e inmanipulable, sin ambigüedades, $\sin$ falsas prudencias, $y$ a la vez fue un apoyo crítico83. La denuncia permanente del fanatismo de ciertos sectores de la izquierda no deja duda de ello84; como tampoco dejan duda de ello las sugerencias que daba al conjunto del movimiento popular.

Cuarta nota. Palabra de esperanza. Para Monseñor Romero ninguna situación por difícil, compleja y trágica que fuese, era insoluble. "Sí hay solución", repitió a menudo. Esta es una de las constantes de su predicación 85 . Y, sobre todo, puso en el horizonte el reino de Dios como fuente de toda esperanza. Su insistencia en explicar el concepto teológico de la escatología muestra ese 


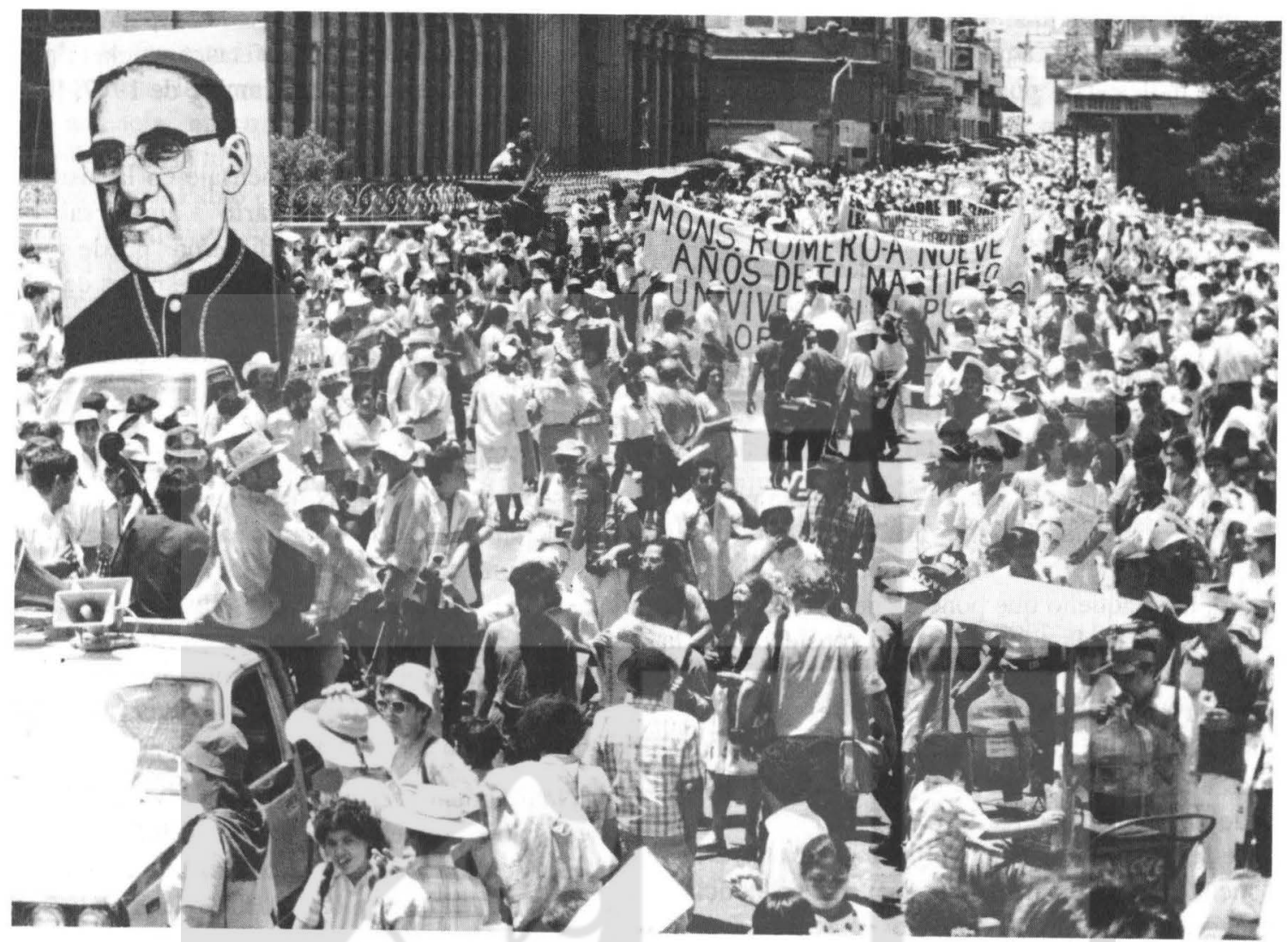

esfuerzo para dar, a través de su palabra semanal, una esperanza al pueblo.

Monseñor Romero se dejó afectar e impresionar por la realidad, y la mostró tal cual es, con toda su carga negativa de injusticia y muerte. Sin embargo, cuando más negativa y cerrada en sí misma estaba la realidad de opresión y muerte para las mayorías populares, Monseñor Romero más se negaba a aceptar fatalmente que no hubiese una salida y comunicaba la esperanza de una solución. Sus homilías transmitieron esperanza a los pobres. Así define él mismo su misión:

Ha sido mi trabajo siempre mantener la esperanza de mi pueblo. Si hay una chispita de esperanza, alimentarla es mi deber; y creo que todo hombre de buena voluntad tiene que alimentarla (11 de noviembre de 1979, VII p. 439).

La predicación cristiana ha de recoger en su conjunto estas cuatro características, si en verdad

quiere ser palabra denunciante y esperanzadora.

\subsection{Palabra conflictiva}

La verdadera predicación cristiana conlleva necesariamente una fuerte carga de conflictividad. Esto es duro de aceptar y poco frecuente. Si algo caracteriza a la mayoría de las predicaciones dominicales de la Iglesia es la falta de conflictividad, ya sea porque elude conscientemente las cuestiones espinosas, ya sea porque el conflicto se considera como algo anticristiano. Sin embargo, la predicación que no provoca conflictos no es verdadera predicación cristiana:

Una Iglesia que no provoca crisis, un evangelio que no inquieta, una palabra de Dios que no levanta roncha -como decimos vulgarmente-, una palabra de Dios que no toca el pecado concreto de la sociedad en que está anunciándose, ¿qué evangelio es ése? Consideraciones piadosas muy bonitas que no molestan a 
nadie y así quisieran muchos que fuera la predicación. Y aquellos predicadores que por no molestarse, por no tener conflictos y dificultades, evitan toda cosa espinosa, no iluminan la realidad en que se vive, no tienen el valor de Pedro de decirle a aquella turba donde están todavía las manos manchadas de sangre que mataron a Cristo: “¿Ustedes lo mataron!”. Aunque le iba a costar también la vida por esa denuncia, la proclama. Es el evangelio valiente, es la buena nueva del que vino a quitar los pecados del mundo (16 de abril de 1978, IV pp. 162-163).

En la Iglesia pesa una falsa idea de la reconciliación cristiana. En nombre del amor, en la predicación y en la evangelización de la Iglesia se omite todo aquello que pone en peligro la armonía y la unidad de la comunidad. Se considera que la palabra y la acción de la Iglesia deben tener un espíritu conciliador. No le faltan razones a este modo de pensar y actuar si con ello no nos situáramos en las fronteras de la complicidad con el pecado del mundo y de la Iglesia. Se comete un grave error cuando se hace del evangelio no ya una "buena noticia", sino simplemente una "noticia", cuando vaciamos el evangelio de su espíritu liberador a fuerza de universalizar su contenido. Ciertamente, la salvación es para todos, mas Jesús anuncia su salvación como buena nueva para los pobres. Todos están llamados a la salvación haciendo como Jesús una opción preferencial por los pobres.

El dilema que plantea Monseñor Romero es claro. La predicación que no denuncia los pecados del mundo no causa conflictos; en cambio, la predicación que denuncia proféticamente el mal y sus raíces origina conflictos:

Queridos hermanos, que no vaya a ser falso el servicio de ustedes desde la palabra de Dios, que es muy fácil ser servidores de la palabra sin molestar al mundo. Una palabra espiritualista, una palabra sin compromiso con la historia, una palabra que puede sonar en cualquier parte del mundo porque no es de ninguna parte del mundo. Una palabra así no crea problemas, no origina conflictos. Lo que origina los conflictos, las persecuciones, lo que marca la Iglesia auténtica es cuando la palabra quemante, como la de los profetas, anuncia al pueblo y denuncia (10 de diciembre de 1977, III p. 45).

Predicar es encarnar el mensaje en la historia. Aquí, encarnar es lo contrario a universalizar. Cuando esto hacemos, la predicación "puede sonar en cualquier parte del mundo porque no es de ninguna parte del mundo". Existen predicaciones en la Iglesia que lo mismo las podemos pronunciar en un país de América Latina que en un país de Europa, y no por ello podemos afirmar que es una buena predicación, sino todo lo contrario, su ineficacia es la misma. No podemos olvidar que la revelación de Dios se encarna en la historia de un pueblo concreto, el pueblo de Israel, y de ese encuentro de la revelación de Dios con la historia del pueblo israelita surge el mensaje escrito, la Biblia. El mismo movimiento debe seguir la predicación, si en verdad quiere revelar la voluntad de Dios para la historia actual.

Naturalmente, esto ocasiona problemas. "No puede haber problemas si estamos hablando de las estrellas", dice Monseñor Romero de una manera metafórica, pero muy clara. El carácter universal de la revelación viene dado precisamente por su encarnación: cuanto más se encarna la palabra de Dios en la historia actual, más universal se hace, puesto que Dios no nos habla desde las estrellas, sino desde la historia actual. Por eso, el predicador no puede perder de vista la historia actual. Son los hechos concretos de su comunidad y de su sociedad los que tiene que "tocar" con su mensaje:

Quiere decir, hermanos, que la historia actual, los acontecimientos de la semana, de este día, no sólo en su carácter nacional sino en un carácter familiar, cada familia ha tenido sus problemas esta semana, más aún, cada uno de ustedes, yo mismo, hemos tenido nuestros problemas, nuestras dificultades personales, familiares, del barrio, del pueblo, de la nación, del mundo, y estas circunstancias actuales no las puede perder de vista el predicador, a no ser que quiera predicar un evangelio que no diga nada a los hombres de hoy. Y esto es muy fácil. Por eso dicen muchas veces: "¿Por qué en tal Iglesia, en tal lugar, no hay problemas?". 
No puede haber problemas si estamos hablando de las estrellas, hablando de las cosas que no tocan los problemas que ejercitan nuestra paciencia, nuestra fortaleza, nuestro compromiso con la historia. La palabra de Dios, pues, según san Pablo en la lectura de hoy, tiene que ser una palabra que arranque de la eterna antigua palabra de Dios pero que toque la llaga presente, las injusticias de hoy, los atropellos de hoy, y esto es lo que crea problemas. Esto es ya decir: "La Iglesia se está metiendo en política, la Iglesia se está metiendo a comunista". Ya aburren con esa acusación (4 de diciembre de 1977, III pp. 19-20).

La predicación no es conflictiva porque la personalidad y el carácter del predicador sean conflictivos. En realidad, la psicología del predicador no tiene nada que ver con la conflictividad de la predicación. No es el predicador lo que causa el conflicto, sino el mensaje que está obligado a transmitir: "La palabra de Dios es conflictiva" 86. Y esta palabra no se puede alterar para vaciarla de conflictividad:

Lo que interesa, pues, es saber que la palabra de Dios es una semilla y que no se puede alterar. Ya quisiéramos una doctrina más acomodada a nuestros intereses. Ya quisiéramos una predicación que no molestara tanto, que no creara conflictos. Pero cuando Cristo plantó la semilla tuvo conflictos, porque esa semilla que es la palabra del justo, del santo, del que sabe lo que quiere cuando ha creado al hombre y a la naturaleza, orienta y choca contra el pecado, contra quienes no quieren dejar crecer esa semilla (16 de julio de 1978, V p. 68).

El predicador no busca a priori el conflicto, lo que busca es quitar el pecado del mundo; cuando el pecado, en sus estructuras y en sus responsables, se resiste y se opone, surge el conflicto:

Naturalmente, hermanos, esto es bien difícil, porque predicar la virtud ante el vicio es provocar conflictos con el vicio; predicar la justi- cia ante las injusticias y los atropellos es provocar conflictos. El evangelio que la Iglesia predica siempre provocará conflictos (22 de abril de 1979, VI p. 314).

Si el predicador para evitar el choque de la palabra de Dios con el pecado del mundo omite la encarnación del mensaje, ciertamente elude el conflicto pero, a la vez, desnaturaliza la predicación, la vacía de revelación y verdad. En realidad, predicación y conflicto son dos realidades inseparables.

Es claro que no toda predicación es conflictiva, sólo aquella que es verdadera predicación del evangelio, la palabra que se pronuncia desde el mismo lugar que Dios la revela: el mundo de los pobres. Allí donde hay predicación que defiende y promueve la vida de los pobres hay verdadera predicación cristiana y hay conflicto con los ricos. Los pobres muestran a la Iglesia la verdad y la conflictividad de su predicación:

Donde quiera que haya un esfuerzo por defender al pobre y promover al pueblo, que deje de ser masa y se convierta en conciencia crítica, allí estorba la Iglesia. Por eso el problema de El Salvador es el problema de muchos países. Donde no se predica un evangelio que provoque este conflicto, naturalmente, no hay conflictos, todo anda bien ( 9 de julio de 1978, V p. 54).

La predicación "no puede agradar a todos"87. Si a todos agradara, algo no está bien. Los efectos de la verdadera predicación siempre son los mismos: los pobres la reciben con alegría, los ricos la rechazan con calumnias y amenazas. Puede suceder, y de hecho sucede, lo contrario: que la predicación la reciban con alegría los ricos y con tristeza los pobres. Entonces, hemos falseado la predicación, hemos convertido la buena noticia para los pobres en una mala noticia, hemos alterado el mensaje. Tal predicación no puede llamarse predicación y mucho menos predicación cristiana.

Monseñor Romero experimentó más que nadie

Una predicación libre de los poderes del mundo es garantía de credibilidad y verdad. 
estas consecuencias intrínsecas que lleva la predicación. Experimentó el rechazo de los grupos poderosos de El Salvador y la aceptación y solidaridad de los pobres, "los sencillos, los hijos de las bienaventuranzas" 88 . En muchas ocasiones, Monseñor Romero constató este hecho:

Hermanos, yo les agradezco a ustedes tantos bellos testimonios de solidaridad, que ya les repetí una vez, que dan ganas de orar como Cristo, sobre todo, entre la gente humilde: Te doy gracias, Padre, porque este servicio a la palabra que yo trato de hacer me lo comprenden los humildes, los sencillos de corazón; cuando, en cambio, se torna diatriba, se torna ofensa y suscita, desata calumnias para todos aquellos que se creen autosuficientes, soberbios, encastillados en su propio modo de pensar y no quieren que nadie les llegue con la doctrina auténtica del verdadero evangelio (23 de abril de 1978, IV p. 189).

Los poderosos expresaban su rechazo a través de amenazas anónimas o calumnias publicadas en los medios de comunicación ${ }^{89}$. Los pobres expresaban su aceptación a través de cartas 90 y, sobre todo, por medio de los aplausos:

No quiero ser yo un acomodaticio para ganarme esos aplausos. De ninguna manera los he buscado yo, ustedes me los han dado espontáneamente. Ni me envanecen porque sé que no es más que la expresión de un pueblo que está sintiendo con aquel que les está dirigiendo la palabra y que está tratando de servirlo precisamente en sus sentimientos más hondos (23 de septiembre de 1979, VI p. 283).

El pecado está tan arraigado en las estructuras de poder y en los corazones de los grupos poderosos que éstos "no quieren oír ni aunque sea un muerto el que les venga a decir: estamos muy mal en El Salvador"9l. Por eso no debe extrañar que la predicación sea rechazada por quienes se aferran a la mentira. Este rechazo, más bien, es una señal de la verdad de la predicación, de su autenticidad.

Asimismo, el pecado oprime en tal medida a los pobres que éstos no pueden menos que alegrarse cuando el predicador desenmascara el poder mortal de ese pecado. Esta denuncia desencadena esperanza. La solidaridad de los pobres con la predicación es garantía de la autenticidad del mensaje:

Cuando un pueblo escucha, atiende y sigue; no digo yo, hermanos, que muchos de los que me escuchan no me escuchan por motivos religiosos - también esa objeción tuve que responderla en Roma-, sé que muchos escuchan con intenciones políticas, con intenciones de cogerme en alguna frase, con intenciones de retarme en algo incorrecto que yo diga; pero sé que la mayoría de quienes me escuchan, escuchan como quien busca la revelación de Dios. Y si alguien no lo hace así sepa que no está en sintonía conmigo, porque yo estoy predicando como pastor, como maestro de la fe y solamente quiero una cosa: que esa fe que yo predico encuentre eco de fe, eco de religión, eco de amor en el corazón de todos ustedes. Y es así cuando el pueblo de Dios es garantía también para asegurarle al predicador que su doctrina, su enseñanza, va por los caminos de la verdadera revelación ( 2 de julio de 1978, V p. 47).

Aceptación de los pobres y rechazo de los ricos son la expresión de la conflictividad de la auténtica predicación cristiana.

\subsection{Palabra perseguida}

"La verdad siempre es perseguida".92 El rechazo de la predicación llega hasta el extremo de la persecución y la muerte de los predicadores. Si es difícil aceptar la conflictividad que conlleva la predicación, más difícil es aceptar el destino de la persecución al que está abocado quien predique la verdad. Monseñor Romero insistió en señalar que la persecución no debe ser motivo de escándalo, es necesaria, es una nota esencial de la autenticidad de la Iglesia y por lo mismo de su predicación:

Siempre que se predica la verdad contra las injusticias, contra los abusos, contra los atropellos, la verdad tiene que doler. Ya les dije un día la comparación sencilla del campesino, me dijo: "Monseñor, cuando uno mete la mano en una olla de agua con sal, si la mano está sana no le duele nada, pero si tiene una heridita, ah, ahí sí le duele". La Iglesia es la sal del mundo 
y naturalmente que donde hay heridas, tiene que arder esa sal. Por eso, la Iglesia tiene como nota esencial la persecución. Y hay momentos en que arrecia esa persecución ( 29 de mayo de 1977, I-II p. 74).

Si persiguieron a Cristo hasta la muerte, no puede ser de otro modo con su Iglesia. La persecución es la piedra de toque que prueba la autenticidad del seguimiento de Jesús. Lo que para unos es escándalo y locura para otros es señal de la verdad:

Lo que se ha dicho en el evangelio de hoy es pura verdad que se realiza también en nuestro tiempo: Si a mí me persiguieron precisamente por la justicia, por predicar la verdad, a vosotros, si os dedicáis a predicar la verdad y la justicia, también os perseguirán. Esta es la señal evidente de la verdad de nuestra Iglesia (20 de julio de 1979, VII p. 97).

Nos hemos limitado ahora a citar solamente aquellos textos donde Monseñor Romero reflexiona sobre la persecución en relación directa con la predicación. Este tema fue muy reflexionado por Monseñor Romero en sus homilías, corresponde a la eclesiología profundizar en los mismos. Baste, pues, constatar la insistencia de Monseñor Romero en señalar que la persecución no es un mal que haya que evitar, sino una consecuencia, trágica, pero inevitable. Si hay Iglesia verdadera sobreviene la persecución. A las clásicas notas fundamentales de la Iglesia (una, santa, católica y apostólica), Monseñor Romero añade otra nota fundamental: perseguida93.

Ciertamente, la Iglesia puede evitar la persecución, pero a costa de traicionar su misión 94 . El escándalo no es que la Iglesia sea perseguida, lo escandaloso sería que, en un ambiente donde reina la mentira y donde los pobres son oprimidos y reprimidos hasta la muerte, la Iglesia callara, no dijera la verdad. Un grave pecado de omisión.

La persecución no sobreviene por defender en la predicación la "pureza" de la doctrina de la Iglesia o por defender principios universales del cristianismo, sino por encarnar esa doctrina en la realidad histórica y en una realidad donde está entronizado el pecado que causa la muerte de los pobres. La persecución sobreviene cuando en la predicación de la Iglesia se defienden los derechos de Dios que son los derechos de los pobres, cuando la predicación es voz de los pobres:

Con este atentado se pretende callar la voz profética y pastoral de la arquidiócesis, precisamente porque está tratando de ser la voz de los que no tienen voz, porque ha estado denunciando la sistemática violación de los derechos humanos, porque ha estado tratando de decir la verdad, defender la justicia y difundir el mensaje cristiano, que desde la época de Jesús escandalizó a los poderosos de su tiempo y, como ahora también, sólo fue escuchado y aceptado por los pobres y sencillos (24 de febrero de 1980, VIII p. 256).

Para Monseñor Romero, los mártires son el testimonio de una Iglesia encarnada en el pueblo95. La Iglesia es perseguida por su opción preferencial por los pobres 96 . Se elimina a los predicadores por "predicar la verdad y señalar los pecados del mundo"97. El verdadero predicador tiene que sufrir la persecución98. Conflicto, persecución y muerte, las notas más desagradables de la verdadera predicación cristiana; sin embargo, estas notas rubrican la autenticidad de la predicación. Una

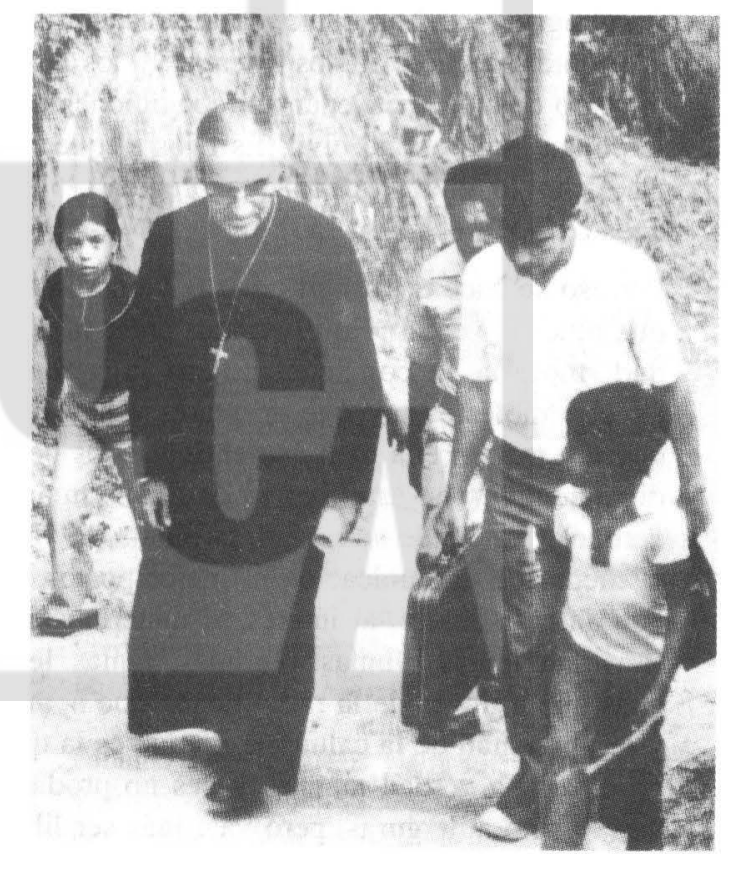


palabra perseguida hasta la muerte contiene la revelación de Dios.

La predicación que es perseguida persiste bajo el signo de la resurrección. Muere el predicador, pero "la palabra queda", precisamente porque no es la palabra del predicador, sino palabra de Dios. Y esta palabra que queda y desencadena esperanza y seguimiento de Jesús es la mayor prueba de que aquella palabra que se pretendió silenciar con la muerte del predicador contenía en verdad la revelación de Dios.

La palabra queda y este es el gran consuelo del que predica. Mi voz desaparecerá pero mi palabra, que es Cristo, quedará en los corazones que lo hayan querido recoger (17 de diciembre de 1978, VI p. 41).

\subsection{Palabra libre y liberadora}

Al decir de san Pablo, la palabra de Dios no está encadenada. La Iglesia - dice Monseñor Romero comentando esta frase paulina - podrá ser perseguida hasta la muerte pero podrá presentar al mundo una palabra libre99. En realidad, la predicación de la Iglesia no está exenta de la tentación de la idolatría y puede ser subyugada por el poder político o por el poder económico:

La obligación del cristiano, del predicador, del sacerdote: obedecer a Dios antes que a los hombres, no dejarse encadenar por condiciones que le ponga la autoridad civil. Es Dios el que me ha dicho lo que se tiene que predicar (6 de agosto de 1977, I-II p. 157).

Por eso se hace tan difícil creer la verdad, porque muchas veces no quisiéramos creer la verdad, molesta la conciencia. Pero la verdad, aunque moleste, hay que aceptarla y hay que querer creer en ella para que el Señor nos bendiga siempre con esa libertad de quien ama la verdad y no vende la verdad, la pluma, la voz, el medio de comunicación al mejor postor, al que da más dinero, al interés, al materialismo. ¡Lástima tantas plumas vendidas, tantas lenguas que a través de la radio tienen que comer y se alimentan de la calumnia porque es la que produce! La verdad muchas veces no produce dinero sino amarguras, pero vale más ser libre en la verdad que tener mucho dinero en la mentira ( 7 de mayo de 1978 , IV p. 210 ).

Nadie puede poner cortapisas al predicador 100 . Es Dios quien manda predicar, es Dios quien dice lo que se debe predicar. Monseñor Romero propone que hay que ser "audazmente libres" de los ídolos del poder y del dinero para predicar la verdad:

¡Qué bella la actitud del hombre independiente! La del hombre que no hace consistir su predicación y su Iglesia en el apoyo del dinero. Esto nos está costando mucho en nuestra Iglesia, hermanos. Esta autonomía del ídolo dinero, del ídolo poder y presentarnos en el mundo como Pablo, audazmente libres. Agradecer al que nos da, pero sepan que no son necesarios, que por eso no me van a condicionar mi predicación. Muchas gracias, pero sepan que yo me debo a Dios y no a ustedes. Muchas gracias, pero sepan que si ustedes se hubieran olvidado de mí, yo les amaría lo mismo y les predicaría lo mismo... De veras, hermanos, yo quiero invocar este valor y esta independencia, esta audacia del predicador auténtico, de Pablo, para decirle a todos los catequistas, a todos los sacerdotes, a todas las instituciones católicas, a todos los que quieran vivir una Iglesia evangélica y auténtica: independicémonos en el sentido no soberbio, orgulloso, sino en el sentido de adorar al único Dios y de poner en Dios toda nuestra confianza (15 de octubre de 1978, V p. 249).

Una predicación libre de los poderes del mundo es garantía de credibilidad y verdad. Sólo así la palabra podrá presentarse de un modo claro y distinto como palabra de Dios y no como palabra de los poderes del mundo. Una palabra servilista es ineficaz, es "lámpara apagada"101. Este servilismo llega al extremo del silencio y la complicidad:

No podemos trabajar por quedar bien con los de arriba. Nuestra palabra en nombre de Dios tenemos que decirla denunciando tantas injusticias. ¡Hay tantas maneras de hacerse cómplice con las manos criminales! La Iglesia no puede complicarse con todo esto, tiene que decir su palabra aun cuando caiga mal (15 de julio de 1979, VII p. 81).

Una predicación libre es inmanipulable. Una 
palabra independiente de los poderes del mundo no corre el peligro de ser manipulada y tergiversada para decir justamente lo contrario de lo que intencionalmente dice.

Cuando hablamos de la predicación como palabra libre no nos estamos refíriendo al legítimo derecho que tiene la Iglesia para propagar su mensaje y doctrina. Nos referimos al carácter inalienable de esa palabra, una predicación que no se vende a los intereses del poder político y económico, una predicación que no defiende lo indefendible, una predicación que, como decía Monseñor Romero, no se confunde "con el barullo de la distorsión, de la confusión, del amañamiento"102.

\section{Conclusión}

Cuando la predicación homilética, tal como nos enseño Monseñor Romero, revela la verdad de la realidad histórica, interpreta esa realidad desde Dios e interpela a los oyentes a transformarla de acuerdo a su plan salvífico, podemos decir en propiedad que esa predicación es palabra de Dios. Las homilías de Monseñor Romero constituyen un modelo excepcional que la Iglesia aclual debe imitar y proseguir. Sus homilías son un "tesoro" que debemos aprovechar al máximo:

Hermanos, guarden este tesoro. No es mi pobre palabra la que siembra esperanza y fe; es que yo no soy más que el humilde resonar de Dios en este pueblo ( 2 de octubre de 1977, I-II p. 261).

\section{Notas}

1. Monseñor Oscar Arnulfo Romero Galdámez (1917-1980) fue arzobispo de la arquidiócesis de San Salvador, El Salvador, desde febrero de 1977 hasta el 24 de marzo de 1980, fecha en la que fue asesinado mientras celebraba la eucaristía en la capilla del Hospital de la Divina Providencia.

2. Las homilias completas de Monseñor Romero han sido publicadas por el arzobispado de San Salvador en una colección de siete tomos titulada Mons. Oscar A. Romero, su pensamiento. En adelante citaremos las homilías indicando la fecha en que fue pronunciada, el tomo y la página donde puede ser encontrado y confrontado el texto citado.

3. Cfr. De la locura a la esperanza. La guerra de 12 años en El Salvador, Informe de la Comisión de la Verdad para El Salvador. Naciones Unidas, San Salvador-Nueva York, 1992-1993, pp. 149-156.

4. Este trabajo, salvo correcciones realizadas para esta publicación, es un resumen de los capítulos II y III de la tesis "Predicación y profecía. Análisis de las homilías de Mons. Romero", Universidad Centroamericana "José Simeón Cañas", UCA, San Salvador, 1993, pp. 24-106.

5. Cfr. Homilias 9 de octubre de 1977, I-II p. 268; 27 de agosto de 1978, V p. 152; 24 de septiembre de $1978, V$ p. $201 ; 26$ de noviembre de $1978, \mathrm{~V}$ p. $323 ; 10$ de diciembre de 1978 , VI p. $25 ; 25$ de marzo de 1979, VI p. 230; 23 de septiembre de 1979, VII p. 283.

6. Cfr. Homilia, 11 de septiembre de 1977, I-II p. 212.

7. Cfr. Homilia, 22 de enero de 1978, III p. 161.

8. Cfr. Homilía 19 de febrero de 1978, IV p. 32.

9. Cfr. Homilía 25 de marzo de 1979, VI pp. 231-233.

10. Cfr. Homilia 6 de noviembre de 1977, I-II p. 305.

11. Cfr. Homilía 20 de agosto de 1978, V p. 134.

12. Cfr. Homilias, 21 de octubre de 1979, VII p. 368; 4 de noviembre de 1979, VII pp. 408-409.

13. Cfr. Homilias 16 de diciembre de 1979, VIII pp. 55_58; 23 de diciembre de 1980, VIII pp. 78-79; 6 de enero de 1980, VIII pp. 131-134; 13 de enero de 1980 , VIII pp. 156-157; 20 de enero de 1980, VIII pp. 247-277; 27 de enero de 1980, VIII pp. 203-204; 17 de febrero de 1980, VIII pp. 247-253; 24 de febero de 1980, VIII pp. 274-277; 16 de marzo de 1980, VIII pp. 354-356; 23 de marzo de 1980, VIII p. 382.

14. Cfr. Homilías 9 de abril de 1978 , IV p. 149; 15 de octubre de $1978, V$ p. $242 ; 31$ de diciembre de 1978, VI p. 89; 22 de abril de 1979, VI p. 311.

15. G. Ruiz, "Un modelo de predicación: la de Monseñor Romero", Sal Terrae 69 (1981/4), № 815, pp. 279-280.

16. I. Ellacurfa, Conversión de la Iglesia al reino de Dios para anunciarlo y realizarlo en la historia, San Salvador, 1985. Originalmente, el capítulo octavo de este libro, "Predicación, palabra, comunidad", fue publicado en forma de artículo bajo el tí́tulo "La predicación ha de poner en contacto vivificante la palabra y la comunidad", Sal Terrae 66 (1978/3), N ${ }^{\circ} 778$, pp. 167-176. Cuando I. Ellacuría escribe este artículo, Monseñor Romero conmociona a la Iglesia y a la sociedad de El Salvador con sus homilías dominicales, $y$ aunque en él no se nombra de un modo explícito a Monseñor 
Romero, es muy probable que se haya inspirado en su predicación a la hora de escribirlo.

17. Homilía 17 de febrero de 1978, IV p. 28.

18. Cfr. Homilia 16 de julio de 1978, v pp. $70-71$.

19. Homilía 26 de febrero de 1978, IV p. 39.

20. Cfr. Homilia 16 de julio de 1978, v p. 72.

21. Homilia 24 de diciembre de 1978, VI p. 56.

22. Homilia 18 de febrero de 1979 , VI p. 153.

23. Homilia 18 de noviembre de 1979, VII p. 464; cfr. Homilía 11 de marzo de 1979, VI p. 199.

24. Homilia 27 de enero de 1980, VIII pp. 183-205.

25. Homilia 29 de enero de 1978, III p. 169.

26. Cfr. Homilia 16 de julio de 1978, V pp. 70-71.

27. Homilia 22 de enero de 1978, III p. 156.

28. Cfr. Homilias 11 de noviembre de 1979, VII p. 421 y 27 de enero de 1980, VIII p. 185.

29. Cfr. Homilía 27 de enero de 1980, VIII p. 184.

30. Cfr. Homilía 16 de marzo de 1980, VIII p. 330.

31. Cfr. Homilía 9 de diciembre de 1979, VIII p. 28.

32. Homilia 25 de septiembre de 1977, I-Il p. 240.

33. Homilia 21 de mayo de 1978 , IV p. 258.

34. Homilia 22 de abril de 1979, VI p. 310.

35. Homilía 28 de agosto de 1977, I-II p. 192.

36. Homilia 8 de julio de 1979, VII p. 61 .

37. Homilia 25 de diciembre de 1977, III p. 98.

38. Cfr. Homilía 17 de febrero de 1980, VIII pp. 229-253.

39. Cfr. Homilía 16 de julio de 1978, v p. 72.

40. Homilia 30 de septiembre de 1979 , VII p. 302.

41. Homilía 2 de julio de 1978, V p. 46.

42. Cfr. Homilía 27 de enero de 1980, VIII p. 193.

43. Cfr. Homilía 17 de febrero de 1980, VIII pp. 229-253.

44. Cfr. Homilía 15 de octubre de 1978, V p. 250.

45. Cfr. Homilía 11 de noviembre de 1979, VII p. 432.

46. Homilía 29 de julio de 1979, VII p. 118.

47. Homilia 30 de abril de 1978, IV p. 193.

48. Cfr. Homilía 25 de noviembre de 1979, VII p. 475.

49. Homilia 23 de septiembre de 1979, VII pp. 275-295.

50. Homilía 14 de octubre de 1979, VII pp. 337-355.

51. Homilía 11 de noviembre de 1979, VII pp. 419-440.

52. Homilía 17 de febrero de 1980, VIII pp. 229-253.

53. Homilia 14 de mayo de 1978, IV p. 244.

54. Cfr. Homilía 15 de julio de 1979, VII pp. 81-82.

55. Homilia 19 de agosto de 1979 , VIl p. 189.

56. Cfr. Homilía 11 de noviembre de 1979, VII p. 440.

57. Homilía 20 de mayo de 1979, VI p. 357.

58. Cfr. Homilias 28 de agosto de 1977, I-II pp.
199-200; 11 de septiembre de 1977, I-II p. 216; 16 de abril de 1978, IV pp. 168-169; 3 de septiembre de 1978 , V p. $166 ; 10$ de septiembre de $1978, \mathrm{~V}$ pp. $175-176 ; 3$ de diciembre de 1978 , VI pp. 11 y $12 ; 24$ de diciembre de 1978, VI p. 76; 4 de marzo de 1979. VI p. 183; 25 de marzo de 1979, VI p. 232; 1 de julio de 1979 , VII p. $49 ; 8$ de julio de 1979. VII p. 66; 15 de julio de 1979. VII p. 79; 2 de septiembre de 1979, VII pp. 218-219; 9 de septiembre de 1979. VII p. 236; 23 de septiembre de 1979, VII pp. 285-286; 30 de septiembre de 1979 , VII p. $314 ; 28$ de octubre de 1979, VII p. $390 ; 11$ de noviembre de 1979 , VII p. $426 ; 16$ de diciembre de 1979, VIII pp. 41 y 51.

59. Homilía 30 de julio de $1978, \mathrm{~V}$ p. 96.

60. Homilia 27 de enero de 1980, VIII p. 186.

61. Cfr. Ibid., VIII p. 186.

62. Homilia 2 de julio de 1978, V p. 46.

63. Homilia 13 de mayo de 1979, VI p. 335.

64. Cfr. Homilía 14 de marzo de 1977, I-II pp. 1-5.

65. Homilia 2 de julio de $1978, \mathrm{~V}$ p. 42.

66. Cfr. Homilias 9 de diciembre de 1979, VIII p. 19; 30 de diciembre de 1979, VIII pp. 93_94; 23 de marzo de 1980, VIII pp. 364-365.

67. Homilias 19 de marzo de 1978, IV pp. 80 y 24 de marzo de 1978, IV p. 103.

68. Homilia 23 de marzo de 1978 , IV p. 91.

69. Ibid., IV p. 91.

70. Cfr. Homilía 2 de julio de 1978, V pp. 46-47.

71. Homilia 14 de octubre de 1979, VII p. 347.

72. Como ejemplo de esto, que fue una constante en la predicación de Monseñor Romero, puede leerse su homilia "La Iglesia santa pero necesitada de purificación" (5 de noviembre de 1978, V pp. 273-287).

73. Cfr. Homilía 6 de agosto de 1978, VII p. 149.

74. Cfr. Homilías 14 de enero de 1979, VI p. 114; 30 de junio de 1979 , VII p. $35 ; 2$ de septiembre de 1979, VII p. $214 ; 11$ de noviembre de 1979 , VII p. 427.

75. Cfr. Homilla 1 de julio de 1979, VII p. 47.

76. La obra de J. Sobrino, Mons.Romero verdadero profeta (Bilbao, 1982) es el primer estudio sobre el carácter profético de las homilías de Monseñor Romero. Su lectura es indispensable para comprender el tema.

77. Homilia 8 de julio de 1979 , VII p. 55-72.

78. Homilia 15 de julio de 1979, VII pp. 73-91.

79. Cfr. Monseñor Oscar Amulfo Romero, su diario. Arzobispado de San Salvador, 1990, 471 pp.

80. Cfr. Homilía 3 de septiembre de 1978, V pp. 160-166. 
81. Homilia 16 de marzo de 1980, VIII p. 348.

82. Cfr. Homilias 23 de septiembre de 1979, VIl p. 294; 30 de septiembre de 1979, VII p. 310.

83. Cfr. Homilías 16 de diciembre de 1979, VIII pp. 58-59; 6 de enero de 1980, VIII p. $133 ; 13$ de enero de 1980, VIII pp. 154-

155; 20 de enero de 1980, VIII p. 178; 27 de enero de 1980, VIII pp. 203-204; 10 de febrero de 1980, VIII pp. 225-228; 17 de febrero de 1980, VIII pp. 251-252; 24 de febrero de 1980, VIII p. 276; 2 de marzo de 1980, VIII p. 304; 9 de marzo de 1980 , VIII p. 324; 23 de marzo de 1980, VIII p. 379.

84. Cfr. Homilia 4 de noviembre de 1979, VII pp. 406-407 y 414.

85. Cfr. Homilias 9 de diciembre de 1979, VIII pp. 18 y $33 ; 16$ de diciembre de 1979 , VIII pp. 41 y 60; 23 de diciembre de 1979, VIII pp. 64 y 73; 24 de diciembre de 1979 , VIII p. 83; 31 de diciembre de 1979, VIII p. 111; 6 de enero de 1980, VIII p. 130; 13 de enero de 1980, VIII p. 146; 20 de enero de 1980, VIII p. 178; 27 de enero de 1980, VIII p. 202; 16 de marzo de 1980, VIII p. 354.

86. Homilia 14 de mayo de 1978 , IV p. 240.

87. Homilía 15 de octubre de 1978, V p. 242.

88. Homilía 9 de julio de 1978, V p. 62.

89. Cfr. Homilía 9 de octubre de 1977, I-II pp. 265-266.

90. Cfr. Homilía 24 de julio de 1977, I-II p. 138.

91. Homilía 25 de septiembre de 1977, 1-1I p. 240.

92. Homilía 29 de mayo de 1977, I-II p. 73.

93. Cfr. Homilía 11 de marzo de 1979, VI p. 190.

94. Cfr. Homilía 28 de agosto de 1977, I-II p. 193.

95. Cfr. Homilía 30 de junio de 1979, VII p. 37.

96. Cfr. Homilia 15 de julio de 1979, VII p. 79.

97. Homilía 7 de mayo de 1978, IV p. 211.

98. Cfr. Homilía 13 de mayo de 1979, VI p. 334.

99. Cfr. Homilia 9 de octubre de 1977, I-II p. 272.

100. Cfr. Homilía 19 de febrero de 1978, IV p. 37.

101. Cfr. Homilía 5 de febrero de 1978, III p. 187.

102. Homilía 15 de enero de 1978 , III p. 148. 